University of Louisville

ThinkIR: The University of Louisville's Institutional Repository

$6-1944$

\title{
A study of forty-three patients who left Waverly Hills Sanatorium against the doctor's advice during the period September 1 through December 31, 1942.
}

Frances Fanelli

University of Louisville

Follow this and additional works at: https://ir.library.louisville.edu/etd

Part of the Social Welfare Commons

\section{Recommended Citation}

Fanelli, Frances, "A study of forty-three patients who left Waverly Hills Sanatorium against the doctor's advice during the period September 1 through December 31, 1942." (1944). Electronic Theses and Dissertations. Paper 1934.

https://doi.org/10.18297/etd/1934

This Master's Thesis is brought to you for free and open access by ThinkIR: The University of Louisville's Institutional Repository. It has been accepted for inclusion in Electronic Theses and Dissertations by an authorized administrator of ThinkIR: The University of Louisville's Institutional Repository. This title appears here courtesy of the author, who has retained all other copyrights. For more information, please contact thinkir@louisville.edu. 


\title{
.UITVERSTTY OF LOUISVILIE
}

A STUDY OF FORTY-THREE PATIENTS WHO LEFT WAVERLY HILLS SANATORIUM

AGATIST THE DOCTOR's ADVICE

DURINO THE PERIOD

SBPTEMBER 1 THROUOH DECBMBER 31, 1942

\author{
A Diseortation \\ Submitted to the Faculty \\ of the Graduate Sohool of the University of Loulavilid \\ In Partial Fulfiliment of the \\ Requiremente for the Degreo \\ of Master of solonoe in social Administration
}

Graduate Diviaion or Social Administration

By

Frances Fanell1

Year

1944 
MALE OP STUDENT: Frances Faneli1

TITLE OF THEsIS: A study of Forty-three Patients Who Loft Weveriy H1lid SanetorIum Against the Doetor' Adrioe During the Porlod september 1 Through Docember 31, 1942

APPROVED BY THE RBADING COMMITTEE COMPOSED

OF THB FOLLOW INO MBMBERS:

John J. Cronin

Annie Louise Pruitt

MAMB OF DIRECTOR, JOhn J. CronIn

DATE: $\quad 6 / 9 / 44$ 
TABLS OF COMTENTS

IIsT OF TABLES ...................

CHAPTAR

I. A BRIEF HISTORY OY WAVRRLY HILIS ......... 8

II. THE PROBLE OF PATTENTS WHO LEATE

ACA TIST THE DOCTOA'S ADVIOE . . . . . . 11

Reason Patients Gave for Leaving Sanatorlum . . 13

III. CHARACTERISTICS OF PATIENTS STUDIED . . . . . 26

Race and sex ................ 26

Age on Admisesion . . . . . . . . . . . . . 27

Marital Statue ................. 28

Bducational Background ............. 31

IV. MEDTCAL DATA

Stage of Disease on Admiseion ........ 33

Stage of D1seace on D1soharge . . . . . . . . 35

Sputum at TIme of Discharge ........ . 36

Clinloel statue on Dlacharge . . . . . . . 37

Length of stay in Senatorlum . . . . . . . 39

Readmissions ......... 40

TIme Interval Between D1sohargo and Death : . 41

v. ECONOMTC AND soctal DATa ............ 42

Employmont of Pationts . . . . . . . . . . 42

Financial statue $\quad .$. ........... 45

Soolel Agency Contacts : : : : : : : : 46

Home Conditions

Medical Attention Since Diachargo ....... 57

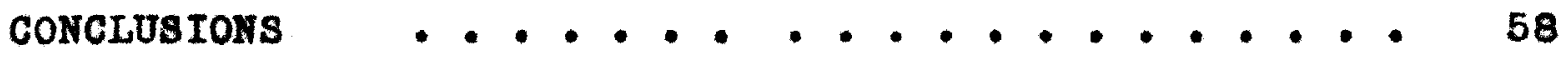

RECOMMENDATIOHS ................ 61

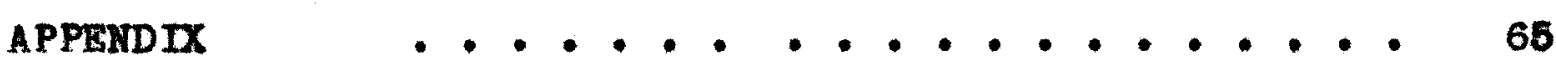

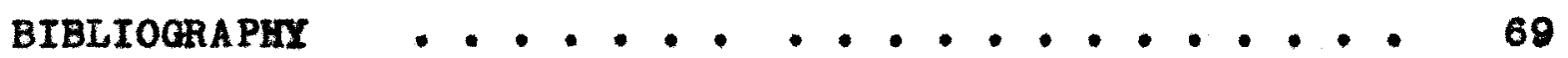




\section{LIST OF TABLBS}

TABLE

PACE

I. Admlesions, Itve D1soharges, and D1echarge

Againet Adv10e, and Peceentage of Live

Dlsoharges Who Ieft Against Adr100 from

Waverly H111. Sanatorium 1839-194?

II. Reason: o1ven for Leaving by 48 Pationta Who Left Wareris H111s During SeptopberDecember, 1942

III. Age of Patiente on Admission clessifled by Sex and Reee..................... 29

IV. Age of Pationts on Admission classifled by Marital statur. . ................ 29

V. Maritel statue of Pet1ente at the pime of Home V1sit classified by Sex and Rave ..... 31

VI. Edueation of Patients Prior to Admission clasalfled by Sex and Reco . . . . . . . 32

VII. Stage of Diacese of Patients on Admisaion classifled by Sex and Rece........... 34

VIII. Stage of Dieease of Patients on Discharge clasalfled by Sex and Reco ...........

IX. Sputum of Petients on Discherge Clasalfied by Sex and Race ............. . . . .

x. Clinical statue of Patients on Discharge Clasalfled by sex and Rece ...........

XI. Length of stay of Patiente in the sanatorium clasalfied by sex and Rece ... ..... 40

XII. Status of cmployment of Patienta at rimo of Admiasion classifled by Rece and Sex . . .

XII. Status of Employment of Patients at Pime of Home visit classifled by Race and sex 
LIST OF TABLES

TABLE

PAGS

XIV. Financial statue of Patient's Fanily at

Time of Admiesion, Dieoharge and Home

V1o1t Clevelfied by Rece and sex ..... 46

XV. Patients Ident1f1ed and Not Identif1ed

by social sorvioe Erohange classifled

by Reco and Sex ................

XVI. Room Accommodetions for Patients Clasa1-

Iled by Sez and Reoe............. 50

XVII. Sleeping Accommodations for Patients

claesifled by Sex and Race .......... 50

XVIII. Room in Petients' Homes by siee of

Patients' Familios

51

XIX. Othere in Patienta' Pamillea X-rayed

or Bramined Classifled by S1se of Family . . 52

XX. Ager of Members of Patienta'. Families

Claseifled by Rase ............ 54

XXI. Problems in the Home classifled by

Reoe and sex

56

XXII. Source of Income of Patients' Famil1es

classifled by Sex and Race . . . . . . 56

XXIII. Medical Attention Recelved or Not Reoelved

by Patients Clansifled by Sex and Race . . 57 
INTRODUCP IOA 
INTRODUCTION

Puxpose of the study

Why do pat1enta leave tuberculosis sanatoria agelnat the dootor's advice? This tudy of home conditione of patients who left Waverly H1110 Sanatorium, Warerly H111s, Kentuoky, againat the dootor'a advice is an ettempt to answer thet ques tion. We belleved that by tudying date rogarding age, sex, occupation and marital status of the patients who left against the doetor's advioe, the sanatorlum and the community could come to some understanding of the reasons for the patient's actions. How many patienta were leaving against the doctor's advice? What wes the 1 se of the problem? Did these petienta have active or arrested cases of tuberculosis? How many were In need of help from soolel egencles at the time of discharge or at the time of admission? Vere they a surce of infection to the community? How long did they stay at the sanatorium? Were the reasone the patients left within the control of the Sanatorium or beyond the control of the sanatorium?

other questione were those in connection with the patient's ability to ajust within the community to whioh he had returned. What clinic supervision did they have after 
leaving the sanatorium? What follow-up was there by the Sanatorium? Did they roturn to work? If 80 , was it injurlous to thelr healthi what was the patient's attitude toward hla famlly? To what kind of homes did they return? These and many other questions well ontered into the Inltial thinking on the study. Dr. Brock, Medical Director of Waveriy H111s, hoped thet interviows with these patiente to secure their reasone for leaving would disclose the underlying factors of the problem.

Method

Aftor chooking flgures at waverly Hills regarding the total who left Waverly H11ls against the doctor's advice, we decided to visit those who lert during the period September 1, 1942 through Decomber 31, 1942. This docision was resched as it was closest to the time that wo were able to visit and it was thought that thore would be less time - lapeed between the time the patient left Weverly H1lis and the time of the home visit, than if those who left earilor in the year were seleoted. The number who left during this period, september through December, 1048, totaled sixtyelght. 
Uning an guide, the sohedule of the National ruberoulosis Association in "A Study of Patient. Diacharged Alive from Tuberouloals sanatoria in 1933", an experimentel sohedule was drawn up and the fifteen who left during the month of Deoember, 1842, were visited. ${ }^{2}$

Whon these visite were completed, the schedule was rovised. 3 There seemed to be 11 ttle use for the question regarding the fomale's malden name, and 1t was omltted in the revisod sohodule. Wo originally thought it might be helprul for Identifloation purposes for olearing through sociel servioe Exohange, or some similar funotion, but this did not prove to be the case. In making the revialon, additional questione were added regarding the problems in the home, as It was noted that the patienta brought out points regarding home conditions thet were not covered in the originel sohedulo.

${ }^{1}$ Jeasamine S. Whitney and Mary V. Dempaey,

"A Study of Pationts Disoharged Allve from Tuberoulosio Sanatoria in 1933". National Tuberculosie Assoclation Research

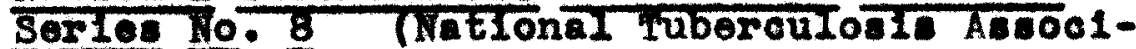
ation, 1948T p. 65

Ef. Appendix A

3 Cr. Appendix B 
Data concerning age, case number, admlttance address, sex, color, ocoupation at the time of admittance, dater of admission and disoharge, diagnosis on admisation and discharge, condition on disoharge, and sutum on discharge was secured from the Sanctorium's Book of Admissions and Disoharges. Marital status, eduoation, employment hlstory, previous and subsequent admissions and discharges, family composition, financial status of the famlly, probleme in the home, sources of income, home conditions and medioel supervision since discharge were secured from the interviews with the patients, or friend or reiative. Verification of previous and subsequent admissions and discharges were found on the face sheet of the petient's medioal chart at the sanatorium. The number of daye the patient was in the sanatorium was also found on the face sheet.

On the basis of the date socured at frerly H1Ils, it was doolded to make no attempt to reaoh ten of the sixty-olght patienta as elght of them I1red outside of the city limits, and two of them ware erroncously listod as LOA (left own accord) the term used by the sanatorium to classify those who left egeinst the doctor's adrice.

In addition to the ten mentioned above, fifteen others wore omltted after attempts to reach them wore made without unccess. Nine of these fifteen had moved and their whereabouts 
could not be traced. Three had returned to waverly H1lle and had dled before an Interview was hold and two other: had moved out of the o1ty. It was not possible to locate anyone for Information regarding those who died at Waverly Hills.

Wo wore ablo to obtain date on forty-throe patients and this number is used for the analysis of the findings. A total of sixty-five visits were made on these forty-three pationts. on twonty-three patients, it wae necessary to secure the information from someone other than the patient because the latter e1ther was not at home at the time of the vialt, or he had moved out of the elty, or the patient had died, or for some other reason. The information on the four patients who had died was obtalned from relatives. Twenty interviews with patients were held. Additional stopa were made to secure date through the Soclal Servioe Exchange. Twenty-nine of the forty-three patients were Identified by the Exchange. Reports from the Tuberculosi: clinio were secured on twenty patients.4 Information on other thirty-five members of the patient's family was obtained from the Tuberoulosis Clinic. Roports were recelved from private physlolan: when the petient Indiosted he had had follow-up treatment from this souroe. Information regarding problems ex1stent in the home at time of discharge and other imilar data was secured from records of soclal agencles the patient or his

4cf. Appendix C 
family may have known. It was not always possible to get data from the sources montioned above so thet some questions on some of the schedules necesserily remeined unanswered. When relative or a eriend was interviewed, information on the petient's education, or some similar points sometimes was not known. In these instences, those questione wore not answered on the schedule.

The aforementioned study made by the Nationel Tubercu10s1s Association on pationts dischargod in 1933 was used throughout this tudy for comparative purposes. Art10les from nowspaper clippings were ource of data. Facta on the history of waverly Hille were taken from unpubliahed meterlal "Wevorly Hille" complled by Mr. W. R. Llvermore, Hospltal Administrator at paverly Hilis. Letters were written to the National Tuberoulosis Assoclation in New York, and to the Vocational Rohabllitation Divialon, Onlted States offlce of Education, Washington, D. C., to socure information pertainIng to b1b210graphy and other dete on the subject. It wes learned from those sources that no similar studies had been made.

Materlal from Wavorly HIlla' Annual Roporta was gatherod to comp12e certaln IIguras. Flgures on pationts who left against the dootor's advice have been kept only alnce 1939. 
GHAPTER I

A BRIEP BISTORY OF WAVERLY HILLS 
CHAPTER I

\section{A BRIEF HISTORY OF WAVERLY HILLS}

In making the study of the patients who loft Weverly H1119, we became interestod in how long the sanatorlum had boen In existence, and what factors led to 1ta establishment. In January, 2907, Waverly H1lls' flrst Board was appointed by the Major, and the flrat bullding was oreoted in 1909. The Senatorlum with a bed capae1ty of forty was opened for patients July 26, 1910; Dr. A. M. Forater, the flrat Medical Director, had ataff consisting of one graduate nurse and three student nurses. In 1911, funds wore appropriated by the city of Loulaville for the erection of hospital for the care of edvanced cases of tuberoulosis. By 1916 Waverly H1ll. was overcrowded with totel of two hundred and one patients. A comittee appointed to make a survey recommended on December 29,1921 , $\$ 1,000,000.00$ Bond Is sue for the construction of new sanatorium. Th1s report was acoopted, and Senate B1II No. 72 authorized a C1ty Ordinance for $\$ 750,000.00$ Bond Issue to be roted on at the November 2922 eloction. After this was pased, Jefferson County added an eppropriation or $\$ 300,000.00$.

The now bullding was begun in January, 1925, and comploted In August, 1926. Immediately following the opening of the now bullding, the unlt used for advanced cases was arranged 
for colored pat1ents, and a complete staff of colored omployees, inoluding rosidont phyolclan and nurses, wore omployed. A nurse's home was bullt and othor provistons for the Increasing staff were made. In 1931 the Board purchased the property at 235 East Chestnut stroet to be ut1lized for the Clty D1apeneary (Waverly H12ls mubereulosis Dioponsary). Since 1923, the Woman's Advisory Board, appointed by the Mayor, has served the patients of the Sanatorium. ${ }^{5}$ Unt11 the merger of Louleville Health Department, Jefferson County Board of Health, and the Board of Tuberculosis Hospital in 1948, Wavorly H121. was governed by the Board of Tuberculosis Hospltal, al-partian Board composed of ten men appointed jointiy by the county Judge and the C1ty Director of Publ10 Bealth. The morger of the health departments was prompted by a recommendation made in a sudy of LoulaV1110' c1ty government in 1935, and a reault of the study made in 1940 of the heal th department of Fayette county, Kentucky. A commltteo appointed by Mayor Scholts in 1940 studied the possiblilty of suoh merger, and In January, 1948, B111 In the Kentucky Leglslature (Senate B1II 35) was pessed consolldating the above-mentloned boards of health. ThI B1ll placed the administration of Wererly H1210 under the Loulevilio and Jefferson County Health Department, which is governed by five-man Board under the leadership of the executive offlcer.

$$
\text { 6. R. Livermore, "Waverly H1Ils" (n.d.) pp. 1-5 }
$$


At the prosent time, Dr. Hugh Loevell holds this position. It was expected thet the merger of the two departments would make for greater offleleney in the avoldance of duplicetion of work. ${ }^{6}$ However, there was a groat deal of readjustment necessary and the perlod covered by this study, septomberDecember, 1942, falls within that period of readjustment.7 Dr. Leavell brought out that not a Ingle nomber of the sanatorium ataff was changed by the Administration after the consolldation. There has beon a considerable shlft of omployeos in recent yoars due to war conditions, physiclens golng into military sorvice and other matters of similar nature.

The addition in 1942 of the greatly needed new bullding for the Hegro patiente brought the bed capacity of the Sanatorlum to flve hundred and seventy-five. Pationts are admitted to the Sanatorlum only through the Waverly H1lls clinie, and they must be realdents of Loulaville or Jefferson County. Payment for care is not accopted, and the institution 1s operated ont1rely with c1ty-county funds.

\footnotetext{
6rows peper ellppings from Louleville Courler-Journel and Times, 1940-1942.

7see p. 11 for superintendent's stetement in 1942 Modionl Roport.
} 
CHAPTER II

THE PROBLEY OF PATIENTS WHO LEAVE AGAINST THE DOCTOR'S ADVICE 


\section{THE PROBLFA OP PATIENTS WHO LEAVE AOAIMST THE DOCTOR'S ADVICB}

The problem of patiente who left against advice has been an inoreasing problem to the sanatorium as indicated by Table I.

\section{TABLE I}

ADMISSIONS, LIVE DISCHARGES, AND DISCHAROES

AGAINST ADVICE, AND PERCENTACE OF LIVE

DISCHARORS WHO LEFT AGATMST ADVICE

FROU WAVERLY HILIS SATATORIOU

$1939-1948^{8}$

\begin{tabular}{|c|c|c|c|c|}
\hline Year & $\begin{array}{l}\text { Admissions } \\
\text { adulte and } \\
\text { ohlldron }\end{array}$ & $\begin{array}{c}\text { Live } \\
\text { discharges }\end{array}$ & $\begin{array}{c}\text { D1 ocharges } \\
\text { ageinst } \\
\text { advioe }\end{array}$ & $\begin{array}{c}\text { Percentage live } \\
\text { discharges who } \\
\text { loft againat } \\
\text { advice }\end{array}$ \\
\hline 1930 & 388 & 298 & 120 & 43.01 \\
\hline 1940 & 417 & 334 & 110 & 32.93 \\
\hline 1941 & 452 & 368 & 160 & 43.47 \\
\hline 1948 & 498 & 360 & 183 & 50.83 \\
\hline
\end{tabular}

of the 6,906 patlente sudied by the National Puberculosis Association, 2,047 or $30 \%$ wore found to have left egeinst the dootor's advice.9

Book of Admiasions and Discharges

I Whitiney \& Dempeer op. C1t. p. 29 
The problem had roached suoh proportions in 1948 that it was discussed at some length by the superintendent at Wavorly Hills. We quote from the Sanatorium's 1942 Modioal Roport:

"A larger percentage of pationts left the Sanetorium againet the advice of the staff during the yoar then in previoua yeara. Thla may be acoounted for chlerly because of general unrest brought about directly or Indirectly by the war. The ohanging of our medical personnel, more partloulerly the physlolans directiy in charge of the patients, caused some confusion among the patients. Th1s has largely been corrected, however, and 1t 1s belleved that this factor w112 be of lesser Importance in the future. Economic difficultios in the home, and homealokness continue to lead as causes for leaving against advico. It is belleved that full-time soclal worker would do much good in helping to alleviate this problem". 10

Dr. Brock brought out in conference that ho thought the current possibilities of making more money was an additiona factor that drew patients away from the sanatorium without the doctor's consent.

It would appear that although the general unrest brought on by the war may be a factor, the problem was a large one before the war started. As polnted out below, 11 economlc factors and homeslokness wore not primary factors for leaving the sanatorium againgt the doctor' advice.

$10_{\text {Annuel Modical Report } 1942, \text { p. } 5}$

II see rable II, p. 14 
Although the group atudied, forty-three patiente, 1. ame11 when compared w1th the total number who lert the Sanatoriun against the doctor' advioe, one hundred and eighty-threel or, when compared with the totel who were discharged or died (476) in 2948 at Waverly H1118, the findinge of this study hould Indicate the problems one might find in a ctudy of a larger sample. The forty-three patients represent $12.0 \%$ of those discharged al1ve in 1942 and $23.6 \%$ of those who 1eft against adv100 in 2942.

Reasons Pationte Gave for Leaving Sentorium

The mein purpose of the study was to determine the reasons why patients left Waverly H111s Sanatorium. In many Inatancea the reaeons were mult1-ceusal rather than un1-oauas.

The reasone 11 sted in Table II are those given by the petients in the pereonsl interviews with them. Although the patients often gave only one reseon for leaving, we were conse1ous of the fact that in most instances there were often underlying reasone. Finanolal reasone as listed in Table II were givon as aditional factor contributing toward the leaving. This point should be kept in mind in interpreting the rigures. For example, some of the nine who left the Sanatorium because of lonesomenese, also indicated 


\section{REASONS GIVEA FOR LEAVING BY 43 PATIENTS WHO LEPT WAVERLY HILLS DURINO \\ SE PTRMBER -DECEMBER, 1948}

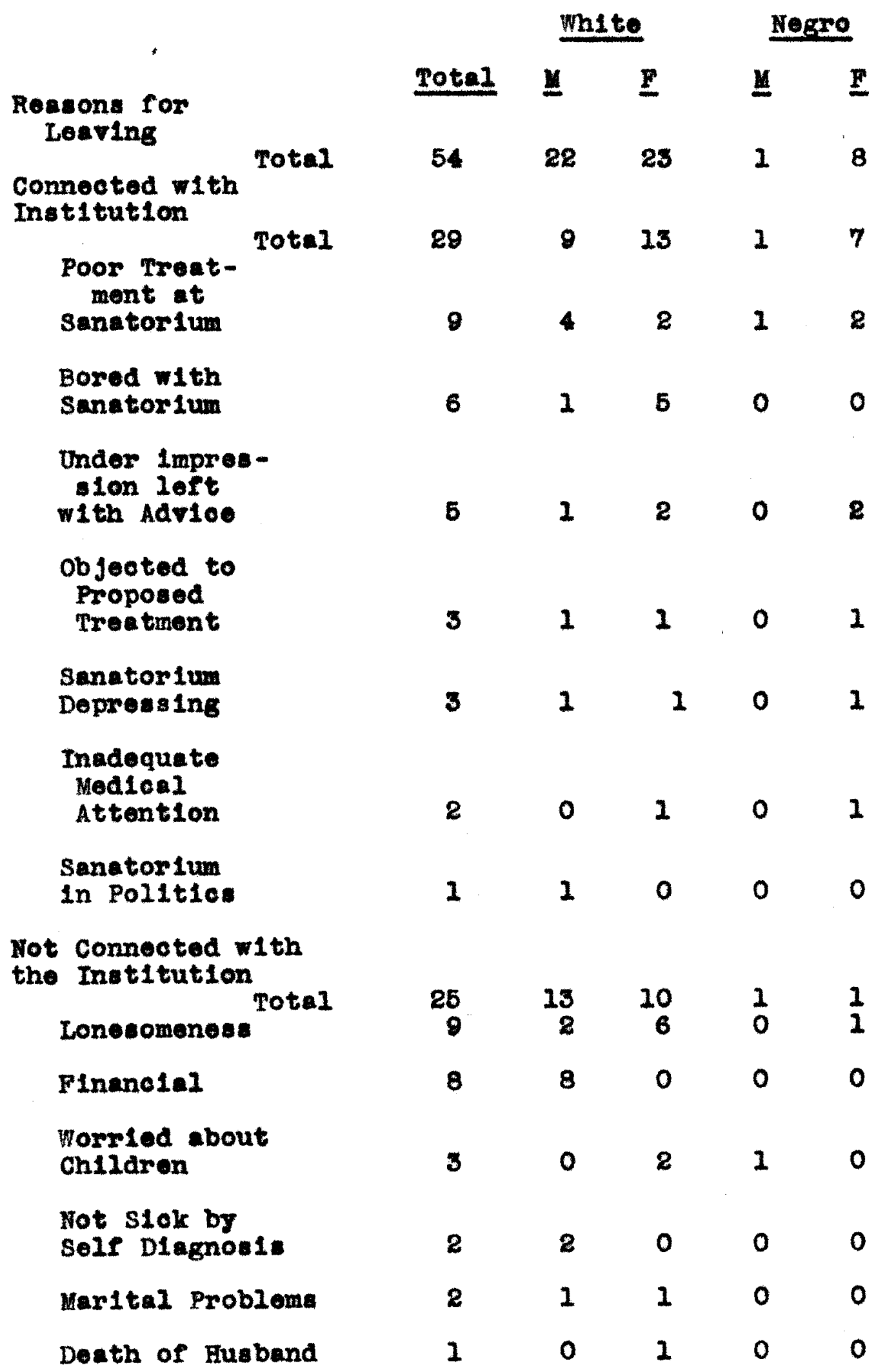


PInanolal or other worries. Likew1se, this same thought should be kept in mind in interpreting the nine of the forty-three patients, who gave poor treatment at the sanatorlum as rowon for loaving. They enumerated along with this, other reasons, such as, boredom or objection to proposed operation. It 1s interesting to note that thirtyfour of the forty-three patienta otudied indicated no dissatisfaction with the Sanatorium. Since the ressone patients gave for leaving were secured from one interview only, it was not possible to ascertain to what extent the reasons they gave had reallty ractors.

Ono should keep in mind that the patients may have had personality difficultion within themselves whioh contributed toward their negative foelings regarding the sanatorlum. In reality there may hare been no basid for tholr foelings.

The interviewer concurs with the statement made in the 1942 Modicel report 12 thet frequently patients left because of the turnover in the medical ataf at that time. The diffloulty of making the tranafor from one phyalcian to another 1s reedily understood when we recognize the importance of the relationahlp between pationt and doctor.

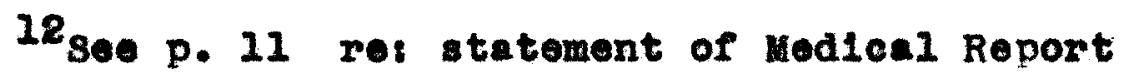


In order to present olearor pleture of the data in Table II, case lliustrations of the patients' reasons for loaving are given:

Mr.C. 18 one of the patients who geve moxe than one reason for leaving. He objected to a proposed operation, and folt that he recolred poor trentment at the sanator1um. At the time he left, he had become progressively worse, and had not reaponded to the now dootor in whom he lacked confldence. After leaving the sanatorlum, he secured treatment from the physlolan he had known at waverly H1118, and in whom he had confidence. He went ahoad with the operation, hls condition Improved and he planned shortly to return to work.

Although Mr.C's fam1ly was able to make a financial adjutmont during the perlod of his 11lness, we might concur that the underlying motivation of $\mathrm{Mr} \cdot \mathrm{C}^{\prime} \mathrm{s}$ aotlon might readily have been his desire to reassume the role of maln wage-earner and head of his family.

10r. D's stuation further 11luatrates patient who gave more than one reason for leaving:

Mr.D., age 44, father of avvon chlldren, also complained of poor troatment of the sanatorium. He blamed the recent merger of the C1ty-County Health Dopartments as the reason for the Sanatorium's inefflolency, and sumed up the whole situation as "politics". His condition when he left the Sanatorium was far-advanced. When he was vilted, he was not working, but folt well enough to be up and about and visit around the nolghborhood. He was satiofied that he was supervising the chlldren adequately while hls wifo worked. Whon questioned bout home conditions, he indlcated that there wore no problems. One of his chlldren had been sohool delinquent unt1I $\mathrm{Mr} \cdot \mathrm{D}$. returned home. 
In the following case story, we got a detalled pleture of patient who thought she was discharged with the dootor's consent; wherees, she was listed on the records as L.O.A.:

\begin{abstract}
Mrs.A., 36-yoar old mother of Nancy, age 11, returnod home under the Impression she had left with the dootor's consent. Hor diagnesis was moderately-advanced when she left the sanetorium. When v1sited, she explained that the was undor the care of private physioian, and underatood that thi plen was agreeable to the doctor at the sanetorlue. When asked for more detalls, she volunteered that mix-up of understanding regarding her loaving the Sanatorlum may have occurred as the whole matter came up when Sergeant $A$. recelred a furlough. Mrs.A. socured permission from her phyalolan to leave when the sergeant arrived. The latter arrived unexpectedly. The doctor with whom Mrs.A. had planned the matter was away from the sanatorium, and Mrs.A. left of her own cocord as the physlolan-1n-charge sould not grent permission to lesve. Mrs.A. was of the Impression that when her doctor returned that her discharge was "with consent" of the Sanatorium.
\end{abstract}

Shortly before and during the perlod of this study, September-December, 1942, the sanatorlum began granting discharges to patients if they worked out adequete arrangements to recelve trestment from private physiolan; or, if they made other satisfactory plans of treatment. Prior to this time, no patient was discharged with the doctor's consent unless h1s condition was diagnosed apparently arrested. In the naturel confusion that arose with the ohange of polley, some patients misunderstood the basis of their discharge. This seemed to be the explanation of those patients who understood they left w1th the doetor's consent. 
When Inquiry was made into certein facts surrounding the manner of discharge in a atudy made by the National Tuberculosis Association of pationts discharged from tuborculosis sanatorie in 1933, It was learned that it was difficult to distinguleh between those who left with the full advice of the medical director, and those to whose departure he gave reluctant consent. Among the latter group were found emotionally unstable patients, those worrled by financial considerations or family problem, and some who tired of the sanetorium. It was pointed out that these factore must be teken Into consideration when the statement that $64 \%$ of the patients $(4,437)$ left the sanatoria in 1933 with the "consent" of the medical director, is considered. Although he "consented" to the patient' departure, he may not have "adrised" 1t. The 2,047 that were liated as lesving agalnst advice, was much more olearly defined. 13

In the following stuetion, we have an 1llustration of a man who apparentiy had boen quite active unt1l suddenly faced with the extreme IImitations made necessary by his tuberculou condition. As result, ur.W. found the sanatorlum deprosesing?

13.mitney \& Dempery, op. C1t., p. 29 
As Mr.W. could not be lookted beceuse he had desorted his ramlly, Mrs. W. gave the necessary information bout hor husband's leaving the Sanatorlum. He was a rostlese, nervous man, who found the senatorium depresing. His diegnosia whon he left the sanatorium efter taying five month. was the came as whon he was admitted, moderately-advaneed. Ho had boen restaurent owner, a gambler, and altogether, a very active individual. Knowledge of hls tuberoulou condition came to him as quite shook. The quiet routine of the senatorium proved to be too great a contrast for Mr.W.

Reasone for leaving given by some of the other petients were influeneed by factors "not connected" with the Inatitution. The following 11lustration show that famliy probleme and personality diffloultios contributed to patient' lesping against the doctor's advioe. Mra.F., for example, left the sanetorium because of Ionesomenese.

Mrs.F. was given a pese at Christmestimo to visit In town with hor family. She prolonged her stay and then as she put 1t "was afrald thoy wouldn't lot hor come beak after thet". Mrs.F., fourful individual of 67 yoars, did not ask the interviewer in but talked with hor in the hellwey. She opoke readily nonethe-10as. VItimetely when the interviewer vorbalized for Mrs. F. her lonesomeness at the Sanatorium, she agreed that this was the real roeson she left the sanatorlum. Before she went to the Senatoriun, her son, grandson and nephow visited hor infrequentiy, but he weloomed these visite and missed them while she was at Waveriy Hills. Hor reletives and friends did not visit her there because they olalmed 1t was too far to the Sanatorlum. Before golng to the sanatorium she had $11 \mathrm{red}$ anely $11 \mathrm{fe}$ with another elderly woman, a companion. She preforred thla to the sanatorlum. Bosdes, she had I1ved in the Haymarket area for years, and was more "comfortable" just being around old familiar objecte. 
Th10 11lustrates how relatives and friends who are not deeply attached to patient use the Inadequacies of traneportation to Waverly Hill as an exoue for not visiting and oaue discontent among the patients.

Tro examples of Individunle drawn home by family probleme; namely, worxy over ohildren and marital prob1ems, are 11lustrated by the cases of Mrs.a. and Mr.E.s

Mrs. Q. returned home beceues of worries regarding her ohildren. Her condition was diagnosed as Minimal when she 1eft the sanatorium after belng there month. Although her 36-year old hueband, 14-year old daughter Betty, and her 10-year and 12-year old sone, Nod and John, wore managlng very well, Mrs.a. was concerned beceuse the thought the ohlldren hed too much respons1b111ty. Since she returned home, whe carefuliy watohed her aetivities so that she would not get tired. Hex children were of grest help to her.

Mr.E. Found it impossible to remain at the Sanatorium when he leamed that his wife wea unfaithrul to him, and thet she wanted divoree. He hastily returned to this olty to attompt to effect a recono111ation. His wife inelsted on the diroroe. Mr.F. continued to find 1t neosesary to remain awey from the Sanatorium to complete final plane for the divorce and make arrangements for the ohildren.

Sometimes the huaband or wife who is left et home to face alone the plans for the children and other family neede finde the going rather diffloult. Hia or her anxieties may increase to the extent thet there may be unressoneble resentment toward the patient's 1IIneas, whioh reantment is 
great enough to cause separation of the couple. This resontmont may also explain soomingly unsympathotic att1tude on the part of the patient' family. In any erent, the patient, such as Mr.E., Finds it necessary to loave the Sanatorium to attempt to work things out.

The fact that many Individual do not foel or look slok when they have tuberoulosis acoounts for the general rostlesaness of some petients. Sometimes they think the doctor does not know what "he is talking bout". Mr.H. Is an examplo of this kind of patient:

Mr.H. left Wavorly H1ll: with alagnosis of moderatelyadvanoed tuberouloais. He had been there five months, and juat oould not belleve he was lok onough to stay. His chart indloated he was active improved; his sputum was negative. He continued to oee private physician in Loulsvilie and understood that h1s condition had Improved. This was later verifled in an interview with the dootor.

Wo from Table II that patiente were drawn from the Sanatorium not only because of family worries, but also because of boredom with the sanatorium and lonesomeness. It is possiblo that these problems might be met in part by medical social worker. The sanatorlum now has an arrangoment whereby patient Is recommended by the physictan for road exereises and oocupational therapy. Possible extenation of this program as it sults the indiridual might be considerod as an important part of the sanatorlum's program. 
An In-Sanatorlum Vocational Training Program would be highly desirable, in thet such program initiated in the Sanatorium would tie up with the state Rehabilitation Service rendered to acceptable discherged patients. The aim, obviousiy, is to diacover patienta' rocational possibilities and to see that necesary training 18 obtained, so that employment becomes avaliable when the pationt's phys 1cal condition permits and after training has been completed. If proper ocoupational plans are made and carried out, the dangers of relapse and the need for further Sanatorium care are diminished. The program has a distnct value to the community 28 well as to the patient, once it definitely is a part of the tuberculosis control program. In addition, it provides goal for the patient whioh aids in mainteining his morale and in obtaining his cooperetion in the prolonged treatment required in tuberculosis.

The fact that treatment of tuberculous persons is primer11y soolal and personal is discussed in an article in the Pam11y, 0ctober, 2932. When complete reat from all soclal and mental activities is presoribed, the patient faces a complete change from his usual way of Iffe in family and home reaponsibilities, occupation, recreation and sex 11fe. Although soclal elements in both cause and treatment are recognized, the greatest contribution of the social worker in 
connootion with tuboroulosis has not been in the form of Individualized case work with the patient himself, but largely in the fleld of prevention. Emphesis for the most part has been placed on communtty and educational work, on promotion of botter housing conditions, higher standarda of living, and on facilitios for examination and treatment of tuberculosis. The patient's personal cooperation is strongif needed in the trestment of tuberculosis.

Although it 1s well known that many tuberoulous petlents show marvelous strength of character, helpfulness and thoughtfulness for others, instances of rapid changes of mood from optimism to discouragement, depression and foars are found. We also find the selfish and the reckles: jeopardizing their own and thelr familles' welfare and the gradual change from adult altruistic attitude to destructive self-centered tralta. There is need for understending of their behavior. The optimism, the spes phthisica formerly mentioned so often has been found to be somewhat mythical. Quite often when 1t does occur, it is because of the patient's desire to show he is playing the game. The social worker should understand and may bo able to help the patlent who drinks to forget his condition or the one who self1shly impregnates his wifo because he wants her to suffer as he does, 
or the one who reels inedequete regarding the possibilities of his return to work. 14

It 1s possible that case work services to Mr.E., Mrs. G., or Mrs.F., might have helpod the patients remain at the Sanatorium. One would hardly expect Mr.E., possibly to lie In bed and walt patiently while Mrs.E. left him for another man. Since his condition was moderately-adranced, he in all probabllity folt well onough to use hls onergles to try and prevent the broaking up of his home. Since the divorce proved to be Inovitable, the avallability of case worker to talk thia through might have helped $V \mathrm{r} \cdot \mathrm{E}$. accept the situation, and draw what potentialities he had within himself to plan a future of hls own. Certainly, plans regarding placement of his chlldron could have been handled by a case worker. These steps might have been faotors contributing toward release of tension within Mr.K., and helped him face the long stay at the Sanatorium.

V1sits by ase worker to the $G$. home might have holped Mrs.G. remain longer at the Sanatorium. Mrs.G. had loto of time to think of possible ways her family was mismanaging her home. Interviews with her might have helped her to understand the reality of the home altuation. Adjustments might

${ }^{14}$ Irene arant, "Soc1al Work W1th Tuberculous Patients", Fam11y, October, 1932, pp. 190-198 
heve been effected by the oase worker through relatives or some other ource.

Mrs.F. spoke very positively of the treatment she recelved at the sanatorlum. If she could have been intervlewed at the sanatorlum, she might have been helped to bring out her feeling of lonesomeness and been encouraged to stay. Relatives and other friends could have been seen for her. Interpretation of Mrs.F's noed of attention, and an occesional visit might have been interproted to relatives and friends.

It is possible that if a soolal worker could have talked with those who gave reasons for leaving that possibly had no reality basis, she may have been able to holp them bring out the underlying personality difficulties. This might have helped them modify their plans so that they would be reallatic and directed toward the goal of complete recovery. The bove discussion seems to point out some of the areas in whlch the case worker could be of service. One can only conjecture what may have happened since other factors of whloh wo are not aware at thi" time may have played an Important role. 


\section{CHA PTER III}

CHARAOTERISTIOS OF PATIENTS STUDIED 


\section{CHARACTER ISTICS OF PATIENTS STUDIED}

As we had hoped when we began our study of the fortythree patienta who left Weverly H111s against the doctor's advice during the period september-December, 1942, comp11ation of rigures on the charecteriatiea of the petients did Indicate sigiflcant findings. The reader w111 note these findings in the tablea regarding sex, rece, marital status, age and education. The significanoe of information such as the majority of the patients studied were married is brought out in the discussion. Similarly, other conolualone were drawn from the flgures regarding ege, sex and education.

Race and Sex

The forty-three patients on whom data was secured were made up of thirty-five white persone and eight vegroes fifteen meles, and twenty-two females. The fect that the Negro group atudied ia amall is understandeble in view of the fact that bed space for Negroes at the Sanatorium 1. IImited. of the totel admiasione in the jear 1942, four hundred were white and ninety-elght Negro. of the total adult patients discharged in 1948, three hundred forty-f1ve were wh1te and ninety-two were Negro. 
The total admisstons and diachargos for 1942 indioated that there were more males than fomalos in both groups. However, for the period studied there were more fomales (28) than males (15) who left against the doctor's advioe.

Age on Admisaion

The largest number of the patients atudied wore in the age group thirty-rive to forty-four (See Table III). There wore no Negroes in this group. The males and fomales were equally distributed as there were aeven in each classification. The next largest number of patients atudied was in the age group, fifteon to twenty-four. There were throe Negroes in this group and nine white patients; all but one of the total were fomales.

The Sanatorium's polloy regarding the admission of chlldren has boen somewhat influenced by the three phases thet treatment of tuberculosia has undergone. During the first phase, emphasis was pleced on discovering the symptoms of tuberculosis, such as, night sweats, tired foeling, eto. It was oventually loarned that by the time a patient man1festod such oymptoms, his condition was frequently too far along to benerit by treatment. 
When this was recognised now plan of action was tried, and the second phase of treatment began. The tuberculoals teat was g1von to all school chllaren w1th the reault that fifty percent of 911 children examined were found to have some Indioation of need for treatment. During this perlod many chlldren wore admltted to waverly H111s. The defriculty of hospitalization soon beome apparent. When it was learned that children for the most part got along just as woll in their homea, and that they were not apt to be infectious, general admissione for children were discontinued. Children are now admitted on the basis of their Individual need for treatment.

Because of the finding in the second phase, which for the most part eliminates sanatorium oare for onildren, omphas in the thira phase hes been placed on finding minimal casea through case finding programs in factorles, schools, clubs, churches, oto.

Marital status

The moat consistent information regarding the marital atetus wes seoured at the time of the home visit. This information was not always ava11able from the records and occasionally was inaccurate. The largeat group of patiente 
studied were married, as shown in Table IV. The total twonty-aix consisted of twonty-four white and two Negro patients. Ten were males and sixteen were fomales.

\section{TABLE III}

AGE OF PATIENTS ON ADMISSION CLASSIFIED BY SEX AND RACE

\begin{tabular}{|c|c|c|c|c|c|}
\hline Age & Total & \multicolumn{2}{|c|}{ White } & \multicolumn{2}{|c|}{$\mathrm{Negro}_{\mathrm{F}}^{\text {Megre }}$} \\
\hline Total & 43 & 13 & 28 & 2 & 6 \\
\hline Under 25 & 2 & 0 & 0 & 0 & 1 \\
\hline 15 under 25 & 12 & 1 & 8 & 0 & 3 \\
\hline 25 under 35 & 8 & 3 & 3 & 2 & 1 \\
\hline 35 under 45 & 14 & 7 & 7 & 0 & 0 \\
\hline 45 under 56 & 3 & 0 & 2 & 0 & 1 \\
\hline 55 and over & 5 & $\mathbf{2}$ & 2 & 2 & 0 \\
\hline
\end{tabular}

TABLE IV

ACE OF PATIENTS ON ADMISSION CLASBIFIED BY MARITAL STATUS

\begin{tabular}{|l|c|c|c|c|c|c|}
\hline Age & Total & Single & Merried & ila. & Div. & Sep. \\
\hline Totel & 43 & 5 & 26 & 6 & 2 & 4 \\
\hline Under 15 & 1 & 1 & 0 & 0 & 0 & 0 \\
\hline 15 under 25 & 12 & 3 & 6 & 1 & 0 & 2 \\
\hline 25 under 35 & 8 & 0 & 6 & 0 & 1 & 1 \\
\hline 35 under 45 & 14 & 1 & 11 & 1 & 0 & 1 \\
\hline 45 under 55 & 3 & 0 & 1 & 2 & 0 & 0 \\
\hline 55 and over & 5 & 0 & 2 & 2 & 1 & 0 \\
\hline
\end{tabular}


Eleven of the twenty-aix fell into the age group thirty-fire through forty-four. Sinee the distribution in the classifications other than marriage was much lower (17), wo can conolude from this fact that the strain of family problome may be atrong factor oontributing toward a patient's leaving the Sanatorium against advice. We may also infor that ince a large proportion of the marriod group are men (Table V) that they may have been concerned about leaving as they were the main wage-earner in the homo. Even though the possibli1ties of their roturning to the home as wage-earner wore alim, the fact that come adjuatment in the home set-up was needed may have influenced the man to leave before it was acceptable for him to do so. M.S. lllustrates the case of male drawn home by rinan01al roasont

Mre.S., 37-jear old wife of Mr.S. 42 yeare, began working when Mr.s. Wag admitted to the sanatorium. It was necessary to leave four children--the oldest a boy of alxteen, and the youngest, a1x-montha old baby. When Mr.S. was interviewed af ter leaving the Sanatorium against the doctor's dvice, he indicatod that his chler reason for returning home was because of the Inadequate inoome in the home, caused by his not boling there. He was concernod liso because of the Inoreased responsiblilty placed on his chlldren with both parents out of the home. The $s^{\prime}$. IIved in a comi-industrial seotion of the c1ty in three room on the socond floor of bullding in poor repair. Mr.S. had roturned to work and had recelved no medical attention alnoe he left Wevoriy Hills of his own accord.

one could discuss at length the potential problems Indicated in this oltuation. Mr.S. mentioned only the 
financial problem. Continued contacte might heve rovealed potentlel problems of the adolescent. We wonder also to what extent Mr.S. 1s infootlous to his baby.

\section{TABLE V}

MARITAL STATUS AT THE TTME OF HOME VISIT CLASSIF IED BY SEX AIID RACE

\begin{tabular}{|c|c|c|c|c|c|}
\hline $\begin{array}{l}\text { Marital statue } \\
\text { Total }\end{array}$ & $\begin{array}{c}\text { Total } \\
43 \\
\end{array}$ & \multicolumn{2}{|c|}{$y^{\frac{\text { Whito }}{1}}$} & 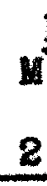 & o \\
\hline S1ngle & 5 & 2 & 1 & 0 & 2 \\
\hline Warried & 26 & 9 & 15 & 1 & 1 \\
\hline W1dored & 6 & 0 & 5 & 0 & 1 \\
\hline Divorced & 2 & 2 & 0 & 0 & $\underline{0}$ \\
\hline Separated & 4 & 0 & 1 & 1 & 2 \\
\hline
\end{tabular}

Educational Background

Deta coneerning educational background of the patlents was socured at the time of the home visit. We were unable to get the data for seren patients elther because wo secured the information from a collateral source and the interviewee did not know It; or, becaume the interview did not offer the opportunity to secure the information.

of the romeining thirty-aix, the largest group were 
those who completed 10ss than the elghth grade. of the twonty-three in this group, nineteen were females and four males. Four wore Hegro and nineteen wore white. (See Table VI).

TABLE VI

EDUCATIOY PRIOR TO ADMISSION CLASSIFIED BY SBX AND RACE

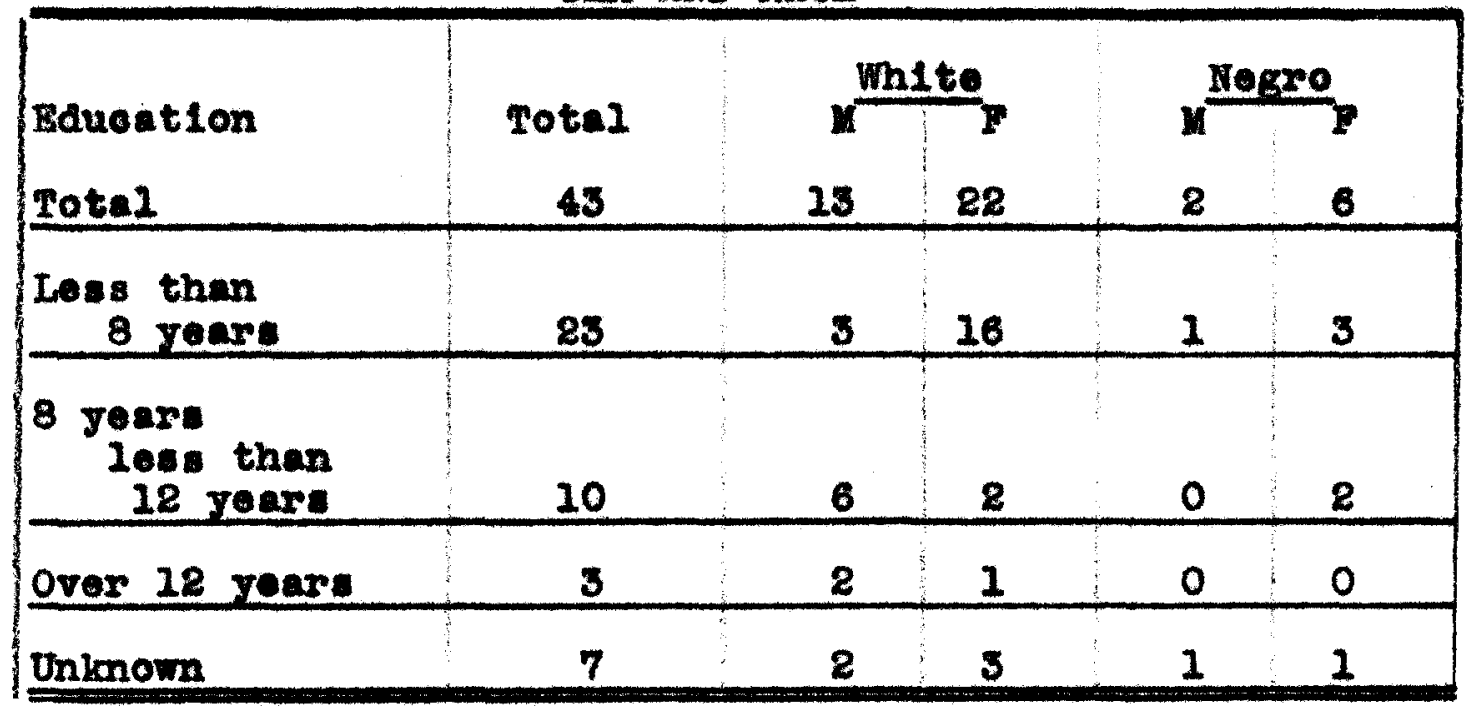


CHAPIER IV

MEDTCAL DATA 
CHAPTER IV

MEDTCAL DATA

As w1ll be noted the data complied in the rables In this chapter was socured $f(a)$ all of the forty-three patiente studied. Information regarding the patient' diagnosis at the time of admiesion and discherge, sputum at the time of discharge, his length of stay at the sanatorium and imilar fecte were cecurod from the record at Waverly Hil2s. Again, the algniflcance of the findinge is brought out in the discussion. The majority of patients who lert againet advice during the perlod atudied, septemberDecember, 1942, had tuberouloa1s in the far-adranced stages. Th1s fact 1s discussed in the 11ght of the totel problem to Wevorly H12la.

Stage of Disease on Admission

For the purpose of thl study, wo w111 use the definltion of "atage of disense" as at forth by the Vocational Rehabilitation Divialon of the Onited states orfice of Education:

"'stage' - mean the oxtent to which the diserse has developed in the lung tiesue. On the Medical Report this w11I be shown as "minimal" moaning thet only a mell area 18 Involred; "moderately-adranced meaning that somowhat larger area is involved; or ' far-advanced' meaning that an extensive aree is involved." 15

${ }^{16} \mathrm{~J} . \mathrm{s}$. Offleo of Education, Vocational Rehabilitation D1vision "Pulmonary Tuberculosis", M1sc. 2328 (Rev1sed) Washington, D.C., Apr11, 1941, p. 6 
It was noted in making this study thet at waverly H111. Sanatorium "moderately-advanced" (MA) and "far-edvanced" (FA) were further described by the use of A, B or C. For examplo, MAA would indicate less activity from clinionl standpoint than MAB or MAC.

of the twenty-one 11sted in Table VII as being in the far-advanced atage, one was FAA and one was PAC. Patients whose conditions were in the far-advanoed stagen numbered h1ghest. of the twenty-one in this group seventeen were females, and four wore males. Four of the twenty-one were Nogro, and 17 white. The next largeat group conslated of those whose tuberoulou condition was in the moderatelyadranced stage. of the total of sixteen, nine were femalea, seven wore males. Thirteen were white and three were Negro. Those admitted in the minimal stage numbered only six, of whom flve were white. (Table VII).

\section{TABIS VII}

STAGE OF DISEASE OF PATIENTS ON ADMTSSION CLASSIF IED BY SEX AID RACE

\begin{tabular}{|c|c|c|c|c|c|}
\hline $\begin{array}{l}\text { Stage of disonse } \\
\text { on Admission } \\
\text { Total }\end{array}$ & $\begin{array}{c}\text { Total } \\
43 \\
\end{array}$ & 13 & $\begin{array}{r}\text { te } \\
28 \\
\end{array}$ & $\begin{array}{l}\mathbf{y} \\
2 \\
\end{array}$ & $\begin{array}{l}F \\
6 \\
\end{array}$ \\
\hline Mintma 1 & 6 & 3 & 8 & 1 & 0 \\
\hline dodorately-adranced & 15 & $\frac{5}{8}$ & 6 & $\frac{1}{1}$ & $\frac{2}{2}$ \\
\hline IA & 3 & 2 & $I$ & 0 & 0 \\
\hline Far-edvanced & I8 & 4 & 13 & 0 & $\mathbf{Z}$ \\
\hline FAA & $\frac{I}{I}$ & $\frac{0}{0}$ & $\frac{0}{0}$ & $\frac{0}{0}$ & $\frac{I}{I}$ \\
\hline
\end{tabular}


Stage of Disease on Discharge

Eighteen of the twenty-three patients who left the Sanctorium in the FA stage were white (Table VIII). Seventeen wore fomeles; six wore males. Twolve who left were in the MA stage; ten of those were white, and two Negro. Elght were remales and four meles.

The olgnificance of these findinge lies in the fact thet the largest group (17 of the 23 far-advanced) w1th the most extenuire activity were fomales. Hore agein, wo become aware of the social problem created in the community. Since we know that the majority who left Waveriy Hills againat the doctor' advice wore married, this additional frotor might ralse the question of what possible chance a mother might have of getting the rost required in viow of the home demends of the mother. We readily tio up the fact that not only is the mother pulled away from adequate oare too soon but also there is the posalbility of the spread of the disease to the children.

TABLE VIII

STAGE OF DISEASE OF PATIENTS ON DISCHARGE CLASSIFIED BY SEX AND RACE

\begin{tabular}{|c|c|c|c|c|c|}
\hline $\begin{array}{l}\text { Stage of D1sease } \\
\text { on D1soharge } \\
\text { Total }\end{array}$ & $\begin{array}{c}\text { Total } \\
\quad 43 \\
\end{array}$ & 13 & $\begin{array}{r}15 \\
22 \\
\end{array}$ & 2 & $\begin{array}{l}0 \\
6 \\
6 \\
\end{array}$ \\
\hline MInimal & 8 & 4 & 3 & 1 & 0 \\
\hline Moderatoly-advanced & II & 4 & $\overline{6}$ & 7 & $\overline{2}$ \\
\hline IA & $I$ & $\overline{0}$ & $\mathbf{I}$ & 0 & 0 \\
\hline Far-2dranded & 20 & 4 & Is & I & $\boldsymbol{Z}$ \\
\hline FAA & $I$ & I & 0 & 0 & 0 \\
\hline FAB & $I$ & $\overline{0}$ & 0 & 0 & $I$ \\
\hline FAC & $I$ & 0 & 0 & 0 & $I$ \\
\hline
\end{tabular}


Sputru at Ttme of Diseharge

Almost half of the croup 2art the sanatorim with a postive oputw. Twonty-throe had negative apatum and trenty hed positive (Table $\mathrm{XX}$ ). or these with positive sputum, serentoen wore wite and three zogwo. Fourteen were fomeles and ix were wales. The conclueten indieated above rogarding the epread of the disenes is rurthor mphasised by these facte alnee hore again the largent group is romele, a large portien of which way be mothore. Allo wo esevene thet whon a pereon leaven a sanatextum with the doetor' consent, he is not roady In any way to roturn to omplojment. Figurea later (Tables XII and XIII, p.44) w111 Indicete that a large group of thom did, Jet the Rehubilitation Agent conalders the statue of the aputum a very important matter in heiping the patient to become adjucted to nomel $11 f$.

"The Information on sputra has two purposes. Firet, 1t Is an important iten in Alagmoale, a posttire sputum being one of the prineipal ormptems of notive tuberou10s10, and ocoond, the rohabilitation agent in occopting responalb111ty for the training and plecemont of ase mast be oure that thore is no danger thet his eliont will infeet other trainees or employees. It 1s, therefore, Important to know flret, that the patient has nogative aputur and ecoond, how long it has been consistontiy negative.

Sputum or othor teste should have beon conslatently negetive for a period of at loat $11 x$ month bororo coteptanco for searvied". 16

$$
{ }^{16} \mathrm{Tb1a} \text {, p. } 18
$$


TABIE $\mathbf{D X}$

SPUTU: OP PATIENTS ON DTSCHARGB CLASSITIED EX SEX AID RACE

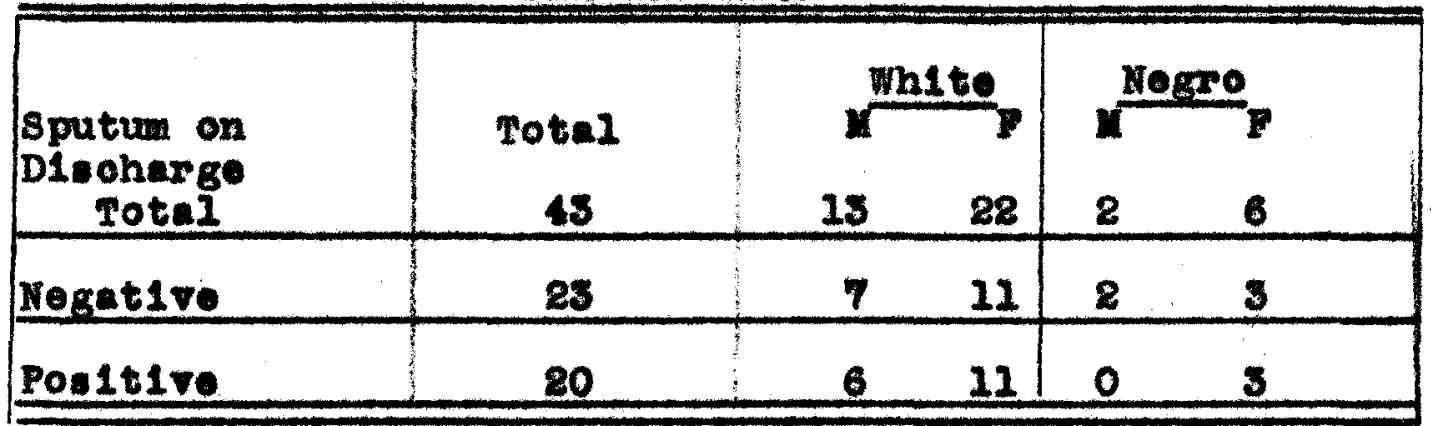

\section{Clinical status on Dlsoharge}

The olinioal statue (Table $X$ ) of the majority of the pationte studied, trenty-one was ative Improved. of these Pifteen were white and six Negro. Twelve were females and nine meles. None of the total forty-three was apparently arrested. This is underatandable Ina smuch as the Sanatorium's polley hes been not to discharge petient with the consent of the doctor unleas he is apparently arrested. Elght of the pationts wore quiosoent.

The above flgures may heve more meaning after we consder the following discussion from the Hationel Tubereulosis Study and the Vocational Rehabliltation D1vialon of the Onfted states Offloe of Bducation:

"Whon a parson who has had the disoase in a faradvanced stage is discharged from the sanatorium as 'epparentiy arrested', hls chanoe for recovery is almost as good as that of the minimal case who 1a 11kewiae considered to be apparently arrested. A patient' 
'with minimal tuberoulosis has an excellent ohance for ourvival, no mattor what his clinical tatus on discharge,.....................nin

"No cseo of active tuberoulosis should ever be accopt-

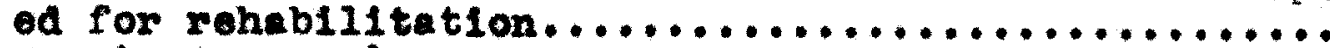
The 'quiosoent' patient is not ready for rehabilitation servioe and none should be undortaken t any point at this stage......... They are not yet froe of the symptoms of tuberculosia............. Apperently arrested patients have been free of the symptoms of tuberculosis

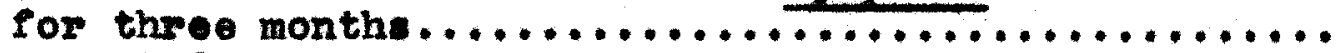
Arreated: .............. They have had a minimum of a1x monthe of freedom from symptom......."18

\section{TABLE $X$}

CLINICAL STATUS OF PATIEYTS ON DISCHARGE CLASSIF IED BY SEX AND RACE

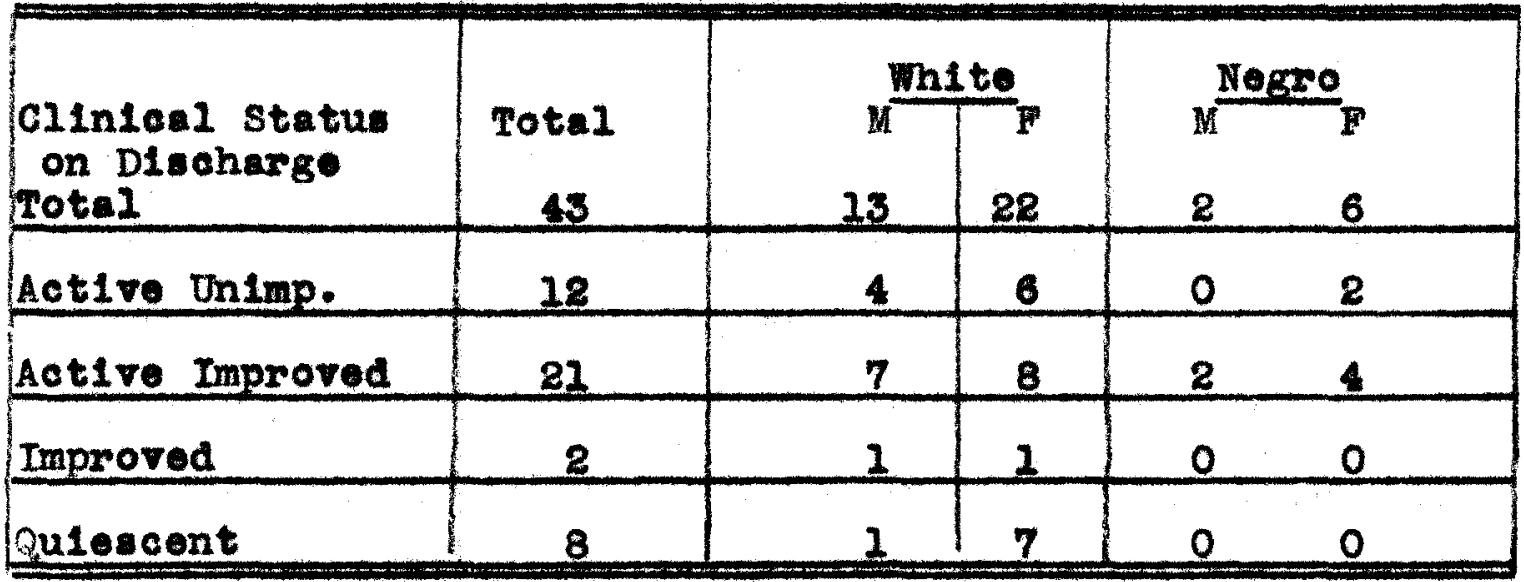

17Whitney \&empsey, Op. C1t.., p. 23

18 United states office of Education, op. C1t., pp. 16-17 
Longth of Stay In sanatoriun

The majority of the patients studled remalned at the sanetoriun only a hort perled. monty-olght of the petionte steyed lese then four monthe, (Table XI) and ten of then stajed los then nine months. Throe of the romalning five wore in the Sanatosive amost two jears. only two remalned wore than two joare. In the atudy of the mational Tubopoulosis Assoolation of patients alsoharged in 1955, It was learned that in opito of the tondoner for most patiente to romiln in cenatorin for relatireIf hor periode, it was erident that the ohanes for aurvirel eubsequent to diacharge Inereased with the length of stey.

The retional study further indleated that only fortyfour pereent of the patients whe remeined in the senatorium for one to three monthe were alive five yeare later. sixty pexoent of all of those who etejed more then two years and left bofore 1035 were et121 living in 1938. The largeat proportion of unrvivore was found mong those whe romulned in the sanntoria for more than three rears. The most important point in conneotion with the length of otey in anatoris is the material reduetion in the generel tuberouloais death rate whioh is effected by remoring patiente with eetive disease from their homes, thue eliminating them as souraen of oxposure to members of tholr nouseholds. 10

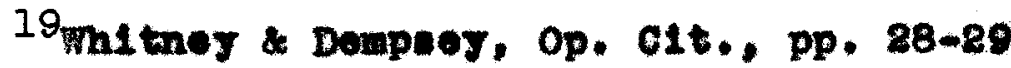


TABLE XI

LENOTH OF STAY OP PATIENTS IN THE SANATORIOU CLASSIFIED BI SAX AID RACE

\begin{tabular}{|c|c|c|c|c|c|}
\hline $\begin{array}{l}\text { Longth } \\
\text { of Stay } \\
\text { Totel }\end{array}$ & $\begin{array}{c}\text { Total } \\
43 \\
\end{array}$ & 15 & $\begin{array}{l}\frac{6}{5} \\
28 \\
\end{array}$ & $\begin{array}{r}1 \\
2 \\
2\end{array}$ & 6 \\
\hline 0 - 4 month & 28 & 8 & 15 & 2 & 3 \\
\hline $5-9$ monthe & 10 & 5 & 4 & 0 & 1 \\
\hline 10-14 monthe & 0 & 0 & 0 & 0 & 0 \\
\hline $15-18$ monthe & 0 & 0 & 0 & 0 & 0 \\
\hline 20-24 months & 3 & 0 & 2 & 0 & 1 \\
\hline orer 24 months & 2 & 0 & 1 & 0 & 1 \\
\hline
\end{tabular}

Readmission:

Only five of the patients studied returned to the Sanatorium. As alsolplinary measure the sanatorium tries to adher to the polloy of refusing ertificlal pnoumothorax treatments to patients who leave the sanatorium against advice. Patiente who are not receiving pneumothorax treatments, but who leave the sanatorium against advice are readmitted at the disoretion of the out-Pationt clinic.20 S1x of the forty-three patients studied had previous admiasions. They were all whlte. One was males three of the five females attempted to work between admissions.

20 Louleri110 Jefferson County Health Department, "To Help you Regain your Health", A GUIDE or Userul Information for Patients of the Waverly H1lis Sanetorlum. (n.d.) 
Time Interval Between Diecharge and Death

It was learned from collateral sources at the time of the home rialt thet four of the petients died. Two were white and two wore Mogro. Two lived lass than two monthe after leaving the sanatorium. One lived four months. One Ilved over five monthe. Agein wo indloate the omall number atudied, in considering these flgures. We refer anew to the study made by the National Tuberoulosis Association as their study was more comprohena1re. Thelr findinge were that only twenty-three pereent of those who left with advice or consent in 1933 died prior to the ond of 1938. Forty-nine percent of the 2,047 who left definitely egainst the advice of the medical director, died during the flre-year perlod. In other worde, sixty percent of those who left "with consent" aurvived the flve years, while only a little more than onethird of those who left against advice, survived this perlod.21

21mitney \& Dempeey, ㅇ․ C1t., p. 30 
Chaprat 7

BCONOMTO AND SOCIAL DATA 


\section{CHAPTER V}

\section{ECONOMIC AID SOCTAL DATA}

Information regarding economio and soclal data as desoribed in this chapter was secured chlefly from hom villte. statements regarding reoont medical examinations wore ohocked with the appropriete clinle or physlolan. A combination of modical and lay opinion is ropresented in the following tables and discuseion.

Bmployment of Pationto

Aa might be expeoted sinee the mefority of the patients studied wore females, the majority of the group were housewives by oocupation. Mineteen of them wore white and one Hegro. Ho table was made of the kinds of employment as they varled to such an extent as to have 11ttle elgnifloance. The occupations of the men ranged from laborer, huckster, warehouseman, and truok driver to salesmen and restaurant owners. Forty wore workIng at the time they wore admitted. (Table XII). Twenty-two were working at the time of the home vinit. (Table XIII).

The findings and conclusions of the Hational Tuberculosis Study rogarding omploymont of pationts holps us in interproting the Ienifloance of Tables XII and XIrI. Thoir fInaings show that in 1938, fire yeare after the 1933 discharge, fewer than 
one-half of the 5,576 pationts then 117ing could be olasalfled as "well"; twenty-two percent stated they wore in "fa1x" condition. Sixty-two percent of the who survived five years after discharge wore roported to be working in 1938; thi. Flgure Ineluded those housowires presumably able to handle their home dut1os. Although modical information was scant, it was noted that two peroent of the living patients were working, though suffering from unstable tuberoulosis.

When the patients who aurvired the flre-year perlod were olassifled according to their clinioal status on discherge, more than half of those in each group proved to have been working in 1938. sixty-nine pereent of those who were apparently arrested on discharge wore employed in 1938. Only fifty-two pereent of those who wore considered errested or apparently cured were at work in 1938. Since the proportion of patients who were reported well in 1938 was smallest for the group with unstable lesions on discharge, and largest for those whose disease was epperently arrested, or arrested at the time of discherge, it seemed that the motivation to return to work depended not only on the petient's good physioul condition but on the nesesulty for carning a living es well.

At later place in the Nationel Study, the comment is made that one eannot assue that 11 of the 625 patienta who were never employed during the 11 ve yeare oubsequent to discharge were too 111 to work throughout this perlod; oven though 
there was widespread unemployment at the time, it was bel1ered thet this was the case In many instances. A rurther comment is made that some patienta who may othewwise be woll onough to work suffor from omotional instablilty to such an extent that they way be unable to secure a job or hold one. Whethor emotional disturbances represent a cause or effeot of tubereuloals 1a point on which athorities differ, yet all agree that many pationte suffer from this handicep. 22

\section{TABLE XII}

STATUS OF BUPLONENT OF PATIBNTS AT THA OF ADMISSIOA CLASSIPIED BX RACE AID SEX

\begin{tabular}{|c|c|c|c|c|c|}
\hline \multirow{3}{*}{$\begin{array}{l}\text { Employment } \\
\text { Statui } \\
\text { Total }\end{array}$} & \multirow{3}{*}{$\begin{array}{r}\text { Total } \\
43 \\
\end{array}$} & \multicolumn{2}{|c|}{ White } & \multicolumn{2}{|c|}{ Hegro } \\
\hline & & & & u & $F$ \\
\hline & & 13 & 28 & 8 & 6 \\
\hline $\begin{array}{l}\text { Working at time } \\
\text { of admittance }\end{array}$ & 10 & 13 & 21 & 2 & 4 \\
\hline $\begin{array}{l}\text { Not working at } \\
\text { time of ad- } \\
\text { mittanoe }\end{array}$ & 3 & 0 & 1 & 0 & 8 \\
\hline
\end{tabular}

22 rold. pp. 35, 37, 40 
TABLE XIII

STATUS OF EMPLONMET OP PATIENTS AT TIME OF HOME VISIT CLAS8IF IRD BX RACE AID BEX

\begin{tabular}{|c|c|c|c|c|c|}
\hline $\begin{array}{c}\text { Employment } \\
\text { Stetud } \\
\text { Total } \\
\end{array}$ & $\begin{array}{c}\text { Totel } \\
43 \\
\end{array}$ & $\begin{array}{r}\mathbf{M} \\
13\end{array}$ & $\begin{array}{l}\mathrm{be} \\
28 \\
\end{array}$ & $\begin{array}{r}1 \\
\mathbf{2} \\
2\end{array}$ & $\begin{array}{l}0 \\
6 \\
6\end{array}$ \\
\hline $\begin{array}{c}\text { Working at } \\
\text { time of } \\
\text { Hone V1a } 10\end{array}$ & 82 & E & 14 & 1 & 2 \\
\hline $\begin{array}{l}\text { Not working } \\
\text { at time of } \\
\text { Home V1sit }\end{array}$ & 21 & 8 & 8 & 1 & 4 \\
\hline
\end{tabular}

Finaneial status

The data for information rogarding financial status was secured from the patient at the time of the home visit. Agenoy recorda also indicated the family's financial status olther borore admittance or after discharge, In some instances. Fortyone of the patients or his famlly wore self-apporting at the time of the home visit. Forty were self-supporting at the time or discharge and thirty-nine at the time of their admisaton (Table XIV). The fact that the possibilities of omployment have been groater in the last fow yoars as compared with oariler depreselon jears, might be considered in connection with the above I1gures, Inasmuch as the period studled 1s recont. Wo might conclude that the main reason that patiente leeve the Sanatorium is not for financial reason as is cometimes generally thought. 
Howerer, many of the familiee did Indionte (Table XXI p, 55) that there were economic problems in the home even though no rellef from a soctal agenoy was secured. Although financial need may not be direct rosson for a patient's leaving, we might infor thet finanolal problems were influenoing factors.

\section{TABLE IV}

F INANCTAL STATUS OF PATIRN'S FAMILY AT TIME OF ADMISSION, DISCHARGE AID HOME VISIT CLASSIF IED BY RACE AMD SEX

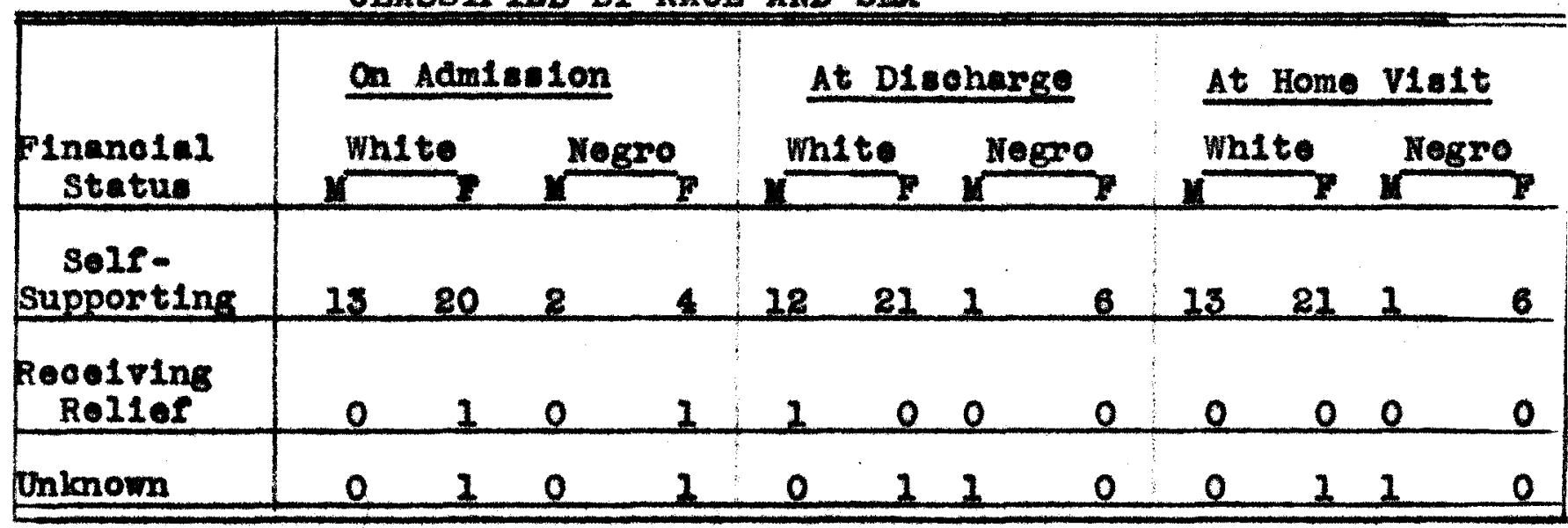

Sociel Agenoy Contecta

More than half of the patients wore known to rerlous soolal egencier in the past (Table XV). Not all of the agenoles were reller agenoles. Hoalth, Chlld Welfare, Delinqueney, group work, Family Welfare and other agenoles were 11ated also. 
Since more than half of the patients sought service of one type or another, we might conclude that probleme wore oxistont in these families prior to the time that the knowledge that tuberculosis was in the home beosme an added diffleulty to be faced. It 1s eafe to suggeat that the avallability of soolal worl services to these familles at the time of their admiseion or at the time the patient expressed any anxiety, might here allerlated some of the patient's worry and helped him to face the long tay at the sanatorium and possibly influenced hil remelning longer. The problems oreated in the home thet we have already mentioned, such as the spread of the disease to small chlloren or other members in the home might be ourtalled.

\section{TABLE XV}

PATIENTS TDETTIFIED AND NOT IDENT IF IED BI SOCTAL SERVTCE EXCHANGE CLASS IP IED BY RACE AND SEX

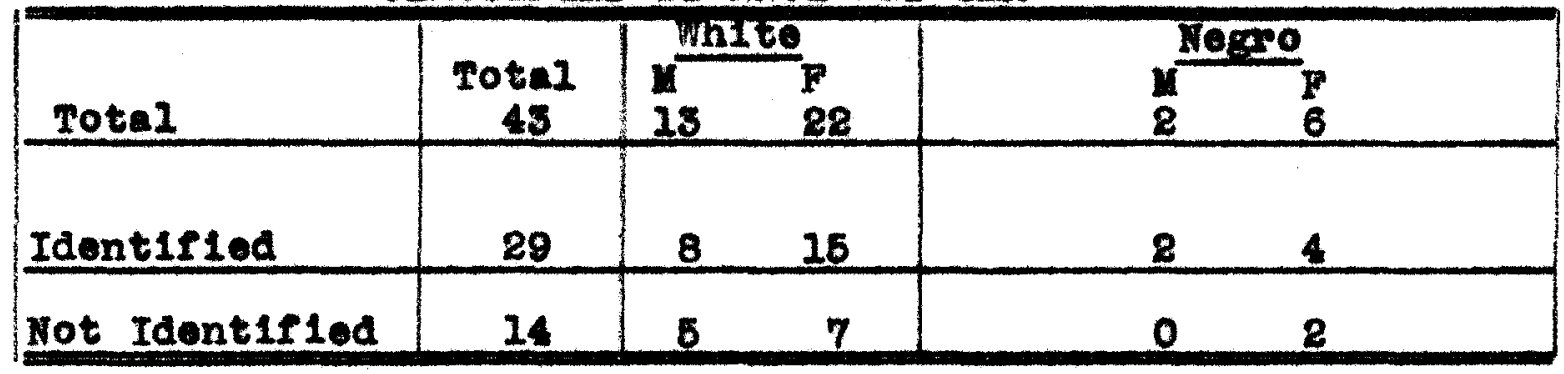

The question of how the avallability of medicel social worker to talk with potients regarding thelr anxieties helped the total medical problem is discussed in an artiole 
from The Fan12r, December, 1038:

Mrs.T. was roferxed by a surgeon to medical soolal worker to disoune an Impending operation. Mra.T. was too "soared" to telk ebout it the flrat time the ooolel worker saw her. The Interviow was direoted to toplca that wore "more comfortable" for the patient to disous and rolationohlp was established whereby the social worker had an opportunity to auggest wooing Mrs.T. aggin and a definite appointwent was made. During the two-dey interval the pationt hed an opportunity to think through the foars he had and was propared to disouse her foeling with the worker. Even so, tho pationt could not be huxried in her decialon and ceveral interviown wore needed, unt1l the patient reached the polnt where the was at osse about the impending operation.

Thls kind of medioel sociel work is differentlatod from the kind of modionl soolel work that requires the attentions of the social worker outside of the institution or hospltal. It It nocessary for hor to help the family left bohind make an adjustment or help arrange for the patient's return home. Both types are easential in the fleld of medioal soolal case work. 23

23 Harriett Bartlett, "Soc1al Case Work: The Contral Funotion of a Medionl Soclal service Departmont". The Fam1ly, December, 1938, p. 248 . 
Hrs.R. was vieited in connection with the followup study of patiente who left Waverly H111. Although her problem was alfforont from Mra.T's, hor aftution might bo disousad here another 111uatretion of how the services of medieal soolal worker might be helpful:

Mra.R': tuberculosia was far-adranced. Family problome caused her to lesve the sanatorlum on sereral oocasion. Onee 1 was neceseary to work out plecoment plane for her children. When this was etisfactorily accompliwhed, we relt it neceseary to lecro the Sen torlum because of her husband' raliure to support adequately. When interviewed, Mrs.R. expressed much bitternose in regard to her huaband' bohavior. Actualiy, although her children wore taken oaro of by aoolal agenoles, Hra.R. kopt herself in an motionaliy upset state by worrying about hor hubband's infidelities.

Th1s altuation 112ustrates to whet extont outs lde home conditions on be edjusted and yet, a need for consultation about innex worries is evidenced. It is not possible to an whether or not Mrs.R. might be helped by regu1ar interviowe at the Sanatorium, but the avaliabli1ty of a medien soolel woxker to talk with Mra.R. and help hor think through an acoeptance of M. $\mathrm{R}^{\prime}$ fallure to aupport, eto., might have positive effect on hor total medionl condition.

Home Conditions

Date regarding home conditions was secured in the interview with elther the petient or ame one who knew the 
pationt's altuation. Twenty-aix of the patients had a room alone (Table XVI), while thirty-one slept alone but may or may not have shared a room (Table XVII).

\section{TABLE XVI}

ROOM ACCOMYDATIONS FOR PATIBNTS CLASSIFIED BY SEX AID RACE

\begin{tabular}{|c|c|c|c|c|c|}
\hline $\begin{array}{c}\text { Room Aocommo- } \\
\text { detion: } \\
\text { Total } \\
\end{array}$ & $\begin{array}{c}\text { Total } \\
43 \\
\end{array}$ & $\begin{array}{r}15 \\
13 \\
\end{array}$ & $\begin{array}{l}\text { te } \\
28 \\
\end{array}$ & 8 & 6 \\
\hline Roome elone & 86 & 9 & 13 & 1 & 3 \\
\hline $\begin{array}{l}\text { Does not } \\
\text { Room alone }\end{array}$ & 17 & 4 & 9 & 1 & \\
\hline
\end{tabular}

TABLE XVIT

SLRBP IMO ACCOMMODATIONS FQR PATIEMTS CLASSIFIED BY SEX AND RAOE

\begin{tabular}{|c|c|c|c|c|c|}
\hline $\begin{array}{l}\text { Sleoping } \\
\text { Aocommodations } \\
\text { Total }\end{array}$ & $\begin{array}{c}\text { Total } \\
43\end{array}$ & & $e_{F}$ & 2 & 6 \\
\hline Sleepe alone & 32 & 9 & 15 & 2 & 6 \\
\hline $\begin{array}{l}\text { Does not } \\
\text { Sleep alone }\end{array}$ & 11 & 4 & 6 & 0 & 1 \\
\hline Onknown & 1 & 0 & 1 & 0 & 0 \\
\hline
\end{tabular}


The largest ramily studied consisted of nine poople. Families consisting of two and four members compriaed the largent group (Table XVIII). Throe, four and Ilve roome seom to be in the maln the number of rooms that the homes ineluded. For the mont part the atudy Indicated thet the patiente returned to orowded home conditions.

\section{TABIE XVIII}

ROOUS II PATIEITS' HOUBS BY SIZE OF PATIEHTS' FAMILIES

\begin{tabular}{|c|c|c|c|c|c|}
\hline \multirow[b]{2}{*}{$\begin{array}{l}\text { rrumber } \\
\text { of } \\
\text { Roome } \\
\text { rotel } \\
\end{array}$} & \multirow[b]{2}{*}{$\begin{array}{r}\text { Total } \\
39 \\
\end{array}$} & \multirow[b]{2}{*}{$\begin{array}{c}\text { Under } 3 \\
16\end{array}$} & \multicolumn{2}{|c|}{ S1ze of Family } & \multirow[b]{2}{*}{$\frac{\begin{array}{c}7 \text { and } \\
\text { over }\end{array}}{1}$} \\
\hline & & & $\begin{array}{c}3 \text { under } 5 \\
18 \\
\end{array}$ & {$\left[\begin{array}{c}5 \text { under } 7 \\
7\end{array}\right.$} & \\
\hline 1 & 3 & 8 & 0 & 0 & 0 \\
\hline 2 & 5 & 5 & 0 & 0 & 0 \\
\hline 3 & 2 & 8 & 5 & 2 & 0 \\
\hline 4 & 10 & 3 & 4 & 3 & 0 \\
\hline 5 & 8 & ? & 6 & 0 & 0 \\
\hline 6 & 3 & 0 & 0 & 8 & 1 \\
\hline Dnknown & 1 & 1 & 0 & 0 & 0 \\
\hline
\end{tabular}

Whon inquiry was made conoerning the extent to which other membere in the home recelved modical attention, we loarned (Table $X \mathrm{XX}$ ) that for the most part, other members of the housohold 
d1d seoure examinatione. Al1 reports regarding medion attention of other nembere of the family were verifled by reports from tho exanining physicina. The majority was examined in the ruboroulosis c11nio. The families of patients who mey here reosired modical attention from a private physiolan, for the most part rere oxamined at the Tuberculosis c1inte.

\section{TABLS $\times \mathrm{D}$}

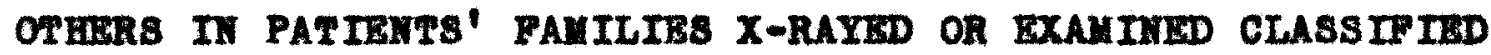
BI SIZB OF PAMILY

\begin{tabular}{|c|c|c|c|c|c|}
\hline \multirow{3}{*}{$\begin{array}{c}\text { Tumber In } \\
\text { Pamily } \\
x-\text { rayed or } \\
\text { Examined } \\
\text { rotel }\end{array}$} & \multirow{3}{*}{$\begin{array}{r}\text { Total } \\
52 \\
\end{array}$} & \multicolumn{3}{|c|}{ S1ze of Pamily } & \multirow{3}{*}{$\mid \begin{array}{c}7 \text { and } \\
\text { over } \\
2 \\
\end{array}$} \\
\hline & & Inder 3 & 3 under 5 & 5 under 7 & \\
\hline & & 16 & 15 & 7 & \\
\hline 1 & 15 & B & 7 & 0 & 0 \\
\hline 2 & 9 & 7 & 1 & 1 & 1 \\
\hline 3 & 4 & 0 & 3 & 1 & 0 \\
\hline 4 & 4 & 0 & 2 & 2 & 0 \\
\hline 5 & $\mathbf{8}$ & 0 & 0 & 2 & 0 \\
\hline 6 and over & 1 & 1 & 0 & 0 & 0 \\
\hline Jone & 4 & 2 & 2 & 2 & 0 \\
\hline
\end{tabular}


Tebles XVIII and XIX total only thirty-nine as the howe conditione of some of the petients who returned to the Sanatoriun could not be tabulated as the family had no home as such. The ohlldren wore in foster homes, in homes of relatives, or In inatitutions and tho othor parent had made different arrangemente. Th1s was true of nome of the faml110s of pationts who had died ince disoharge.

A study of the ages of the other members of the household (Table XX) Indiceted that for the most part the patients retumed to homes whore there were amall ohlidren. Previoue studies have Indicated that tuberoulosia takes ito highest toll in the ago group fifteen to forty-f17e. The flgures bhow to what extent this age group was exposed to active tuberculosis by the return to the home of patients who left the sanetorium againat the dootor' adrice.

Probleme extant in the homes to which the patients returned are shown in Table XXI. Although the interviewee did not always bring out these problems being the ohler rosen for loaving the santorlum, they wore seoured from the interviow al wholo and may easily have been contributing factora In drawing the patiente away from the sanatorlum. The roader should keep in mind in noting the problems listed in Table XXI 
that these diffloulties wore brought out in the home visit. Since the petient was not familiar with the interviewer, he may not have disoussed 211 of his problems nor the magnitude of them.

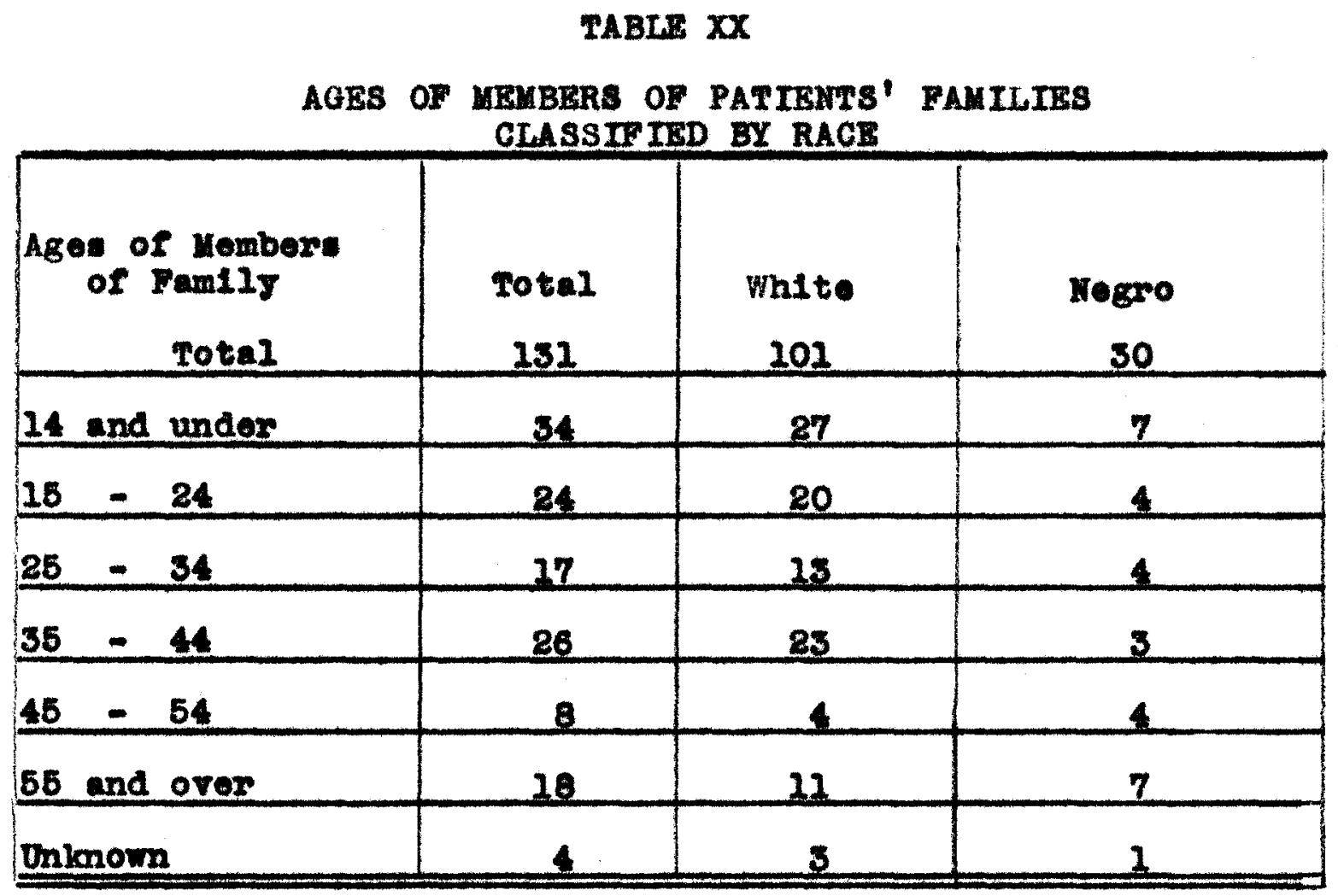


TABLE XXI

PROBLEYS IA THE HOUE CLASS TPIBD BY RACE AND SEX

Problome Found At Time of Discharge

At Time of Home Vialt

Total ${ }^{\text {White }}, \mathrm{Negre}^{\text {Neg }}$

Total White $u^{\text {Negro }}$

1. Inedequate Ineome

184

40

102

40

4

2. Dnemployment

20

20

3

21

1

3. IIIneas or

Diaability

21

0

2

62

20

1

4. Broken

Fam127

72

30

$7 \quad 2$

40

1

5. Behevior

Problem

(a) adult

\begin{tabular}{rrr|r}
13 & 3 & 7 & 2 \\
4 & 1 & 2 & 0
\end{tabular}

$\frac{1}{2}$

$\begin{array}{rr}10 & 2 \\ 4 & 1\end{array}$

70

1

(b) onlid

2

1

30

21

10

7. Inadequate

Supervision

of onliaren 72

10

0

1

30

2

73

30

1

8. Probleme of

Adoleseonce 20

10

1

20

10

1

9. Confliot with relative

10

2

52

80

1

10. Confliet with comaunity 3

20

21

10

0

11. Montal III-

$$
\text { noes }
$$

00

00

0

00

00

0

12. Mental DePlolenor 
Inoomes of the patienta! familien wore principaliy from private industry (seo Table XXII). Here again wo beoome arare of the elnanolal Independence of the group atudied, but wo might t1e up this point with the fast that the perlod studled was more prosporous than oarller yoars.

TABLE XXII

SOUROB OF INCOME OF PATIENTS' FAMILIES CLASS IFIED BY SEX AND RACS

Soures of Inoome

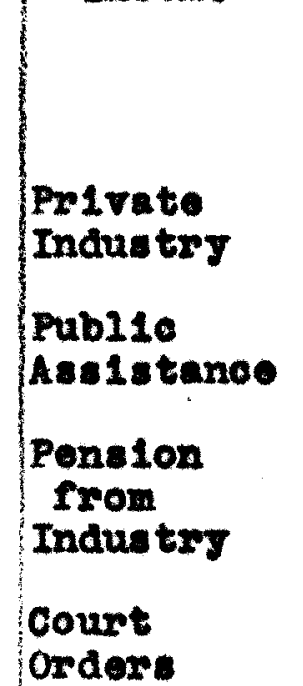

Aass 1otance rrow Relatives

Boardera and Lodger: Army and ) Nery pay Private Agenoy Unknown
At rime of Home V1alt rotal White ${ }^{\text {Negro }}$ $\begin{array}{llll}36 & 11 & 17 & 8\end{array}$ $\begin{array}{lllll}33 & 10 & 17 & 1 & 5\end{array}$

$\begin{array}{llll}0 & 0 & 0 & 0\end{array}$

0

1010

0

1010

0

1010

0

$\begin{array}{lllll}0 & 0 & 0 & 0 & 0\end{array}$

0000

0

$3 \quad 810$

$\begin{array}{llll}3 & 2 & 1 & 0\end{array}$

0

o

0000

0

$\begin{array}{llll}0 & 0 & 0\end{array}$

0

$8 \quad 2 \quad 3 \quad 0$

3

4130

3

1200

0 10001

0

0000

0 $\begin{array}{lllll}0 & 0 & 0 & 0 & 0\end{array}$ 
Medicel Attention Since Discharge

Thirty of the patients continued to recelve medical attention aftor leaving the sanatorlum. All but ten of these patients obtalned treatment elther truberculosis clinic in Loulstille or at Waverly Hills. The ton patients who wore treated by private phyaleians wore whites five fomales and fire males (Table XXIII). IAIl patiente disoharged from the sanatorium are requested to return to the clinic at regular intervals. If this does not happen the clinio requests them to come in for examination. The sok patients recelve nursing service from clinlel.

\section{TABLE XXIII}

MEDICAL ATTETPIOI RECEIVED OR NOF RECBIVED BX PATIBNTS CLASS IF IED BY SEX AND RACE

\begin{tabular}{|c|c|c|c|c|c|}
\hline rotal & $\begin{array}{c}\text { Total } \\
43 \\
\end{array}$ & $\begin{array}{r}1 \\
15 \\
\end{array}$ & $\begin{array}{l}28 \\
28 \\
\end{array}$ & $\begin{array}{l}1 \\
2 \\
\end{array}$ & $\begin{array}{l}0 \\
6 \\
\end{array}$ \\
\hline $\begin{array}{l}\text { Rooelving } \\
\text { Modical } \\
\text { Attention }\end{array}$ & 30 & 8 & 16 & 2 & 4 \\
\hline $\begin{array}{c}\text { Not } \\
\text { Recelving } \\
\text { Medioal } \\
\text { Attention }\end{array}$ & 13 & 5 & 6 & 0 & 2 \\
\hline
\end{tabular}


CORCLUS TONS 
COMOLUSIOHS

1. The majority of patients leave Weveriy H1110 because of boredom, rostlessnese and lonesomeness.

8. Although the group studied 1. amall in relation to the total population at Wavoriy H111s, It would secm an Indieation that more mothore leave Warerly Hille againet the doctor's advioe than pationts having other atatue.

3. Mot only wore the majority atudied mothors, but the age coup found most frequently in the homes to which the patiente returmed was loas than fourteon. This leads us to conolude that in the main the group leaving agalnet the adv100 of the doctor wore dram because of home reaponalb111t10s and care of the onlidron.

4. Patiente whose condition 1s fartheat adranoed are leaving the sanatorium agalnat the dootor's adriee.

6. Almost half of the patiente who leave the sanetorIwe egainst the doctor's adr10e have positive oputum.

6. More than half of the patients who loft Wavorly H111. againgt the doetor's adrloe during the porlod studied had active pulmonary tuberoulosis.

7. Since the majority of patients atudied romained 10as than four monthe and ince wo lmow that a long stay is escential for any improvoment of a tuberoulous condition, we 
can safely conolude that patient: who loave sanatoria against the doctor' adrice have less ohance of improving their condition than those who remain the full term demanded to be oured. This point as well as conclusion 4-5-6 readily Indicate to what extent there could be spread of the disease In the oommanity.

8. The faot that chanees of patients who leave sanatoria againat the doctor' advice to make omployment adjustment are lossoned 1s concluded whon wo learn thet helf of the pationts atudied were unemployed when the home visit was mede.

9. Mone of the patients oame from homes that were recelving rinanolel holp from social agency at the time of home visit. One patient was recoiving relior at the time of discharbe; only two st the time of admisalon. The finanolel status of only one patient was unknown.

10. Although no date was oollected on actual family inoome, It would appear rrom problems listed by the patients that Inadequate inoome was an Important problem in many of the homes. Th1s auggeste thet an adjustment of one kind or another in thi. area was nooded. The problem of insufficlont inoome was socondary only to behavior defloultion. 
11. Almost a third of the pationte sudied recolvod no modical attention since loaving the sanatoriwe.

12. Home acoomodetions for the patients were 1imited. Whon the fact that the majority roomed and alept alone is compared with the fact that the arorage number of rooms for the families of the patiente is leas than one soom por porson, we axpive at the above conelueion.

13. On the whole the familiea of the patient: had some modicel attention. The majority was examined at waverly Hill. ciln10.

14. Lose than olghth grade education was secured by the majority of patienta studied. 
RECOMMEMDAT IONS 


\section{RECOMMENDATIOWS}

Since the sanetorium is concerned about the pationt who leares agalnat the doctor's advice, and at the conolualons would Indioate that many probleme are oreated in the community by the patients' self-disoharge, it 1t recommended:

1. That the Oooupational Therepy Dopartment expand thelr atiritiea for petiente both ambulatory and nonambulatory, but who noed some type of mental aotivity to reduce beredom and restlessness. Possible development of vocational training might be ineluded.

2. That as a beginning plan, one full-time medical social worker be omployed to interview the patients regardIng their worries and problems.

a A soolal worker could arrange for the proper soc1el egenoy to muke contact with the pationt's ramily to attompt to adjust tho home situation if that 1s the problem, and thue rellere the petient from his anxiety regarding his return home.

b. Follow-up of patiente who leeve ageinst the doctor' advice might be done by the social worker. Thls might include help toward solvIng home problems which are bothering the patient. Then the petient might be encouraged to return to the sanatorium. 
c. If the patient wore unw1111ng to roturn, interpretation of the pationt' noed could be mede to his ramily with the hope that with better underetranding of the problea, the patient, a well as the family. oan bonorit.

d. Intexpretation to the patienta' families regarding visiting and the patient's need for outside conteote could be given so that the patient would hive $100 \mathrm{~s}$ chanes to become merbla over a posalble reeling of bocoming "lost" to the outside world.

- The aervioe of holplng patient talk through a worry that way heve soechod unrenl proportlons could be given by the cosial worker.

3. Thet Waroriy Hills Sanetorium direot future planning to inolude omployment of more than one medical soclal worker, depending on the extent of the need for soclal work In the senctoriva.

4. That the serviees of a paychiatriet bo omployed to help the reetlese, nervous patient meet his complete change in situation.

6. That a plan be worked out botween the health and welfare departmente for adequete Inancial aeletaneo to fanl11es of patiente who are admitted to Waverig Hi11s. This might be readily accompliahed alnoe both departmente are publis 
agoneles aupported by taxes. The plen might holp tho patient romain at the sanatorium the rull term roquired of him as economic worries would be minlmised. 


\section{APPEIDIX}


1. Name of patient.......................... 2. Date of birth......

3. Sex.... 4, S.M.W.D. Sep. (Chook) 5. Color....6. Conmitment addreas

7. Other addresses.

8. If female, maiden name.........................

9. Education prior to admisalon (a) Erado completed 123456789101112

(b) oolloge 1234 - post Eraduate 1234

(c) spoolal training

10. Exployment before edinttence

intervals betwoen admissions

11. Onset of disease (date)...... 12. Date of commitment...... 13. Date of discharge........... (a) length of twy (days) 14. (a) prevlous adnission ................... (b) subsequent adniselons (dates)........

15. If dead, (a) dato of death.

16. Diagnosis (a) on edal ssion.....................(b) on discharge....... $\bullet * * * \cdots * \cdots * \cdots \cdots$

17. Condition on discharge (a) active...... (b) unimproved... (c) improved.. (d) quiesoent..... (e) apparently arrested..........

18. Vocational training at Senatorium, Yob.... No.......

19. Family (11st all living in seme household) Nerne Date of birth

Eave or had T.B.

Present heal th (if T.B. tested or $x$-rayed indicato)

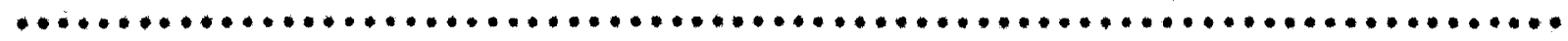

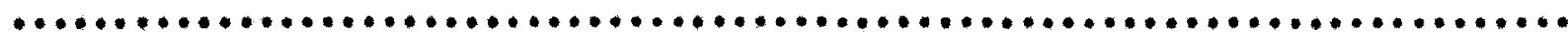

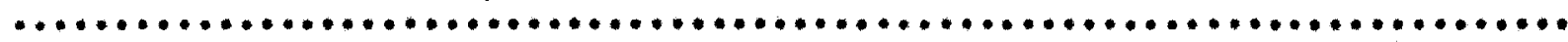

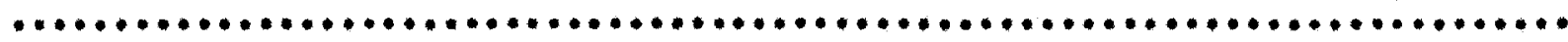

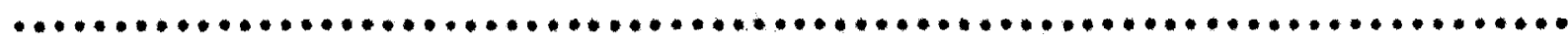

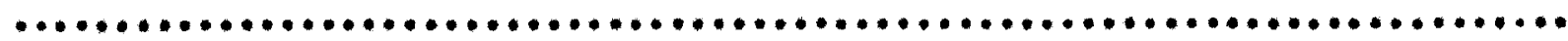

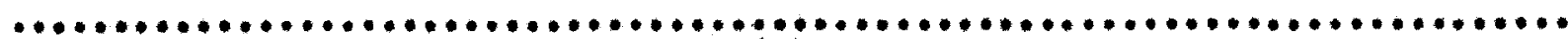

20. Finanolal statue on adulseion: (a) 1s patient self-supporting?.........

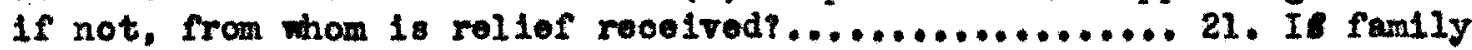
self-aupporting? If not, from whon is relief reoeivedi..............

22. Home conditiona! (a) Bo. of rooms..... (b) Patient room alone?........ (e) sleep alone? .............

23. SSA C2ouringe:

(a) Nane of agency active if any.
}

24. What medion oupervision since discharge?

(a) Datest From......... To........... (b) By................

25. Date (a) of last exemination....... (b) last X-ray......... (o) Rosult... ................. 26. What is present condition?

27. Why did you leave sematorium? 
Date of home visit..................

1. Name of patient............... Age........ 2. Case number........

3. Adnittance addrosa.

4. Name of husbend or $\mathbf{w f}$ or relatives..........................

5. Address.......................... 6. Other Addresses..............

7. Sex....... 8. S. H. W. Sep. (cheek) s. color.................

10 Eduoation prior to adnisaton, (a) grade completed 123456789101112

(b) oollege 1234 post graduate 1234

(c) pootal training

11. Decupation at time of admittanes

12. Buployment before adnittance

- between admisstons

" at time of home vialt

13. Date of actuission....... Diagnosis..... Dato of discharge... Diagnosis.. Day in hospttal..............

Date of previous admision.... Diagnosi...... Date of discharge......... Diagnosis..... Days in hospital .........

Date of subsequent admission....... Diagnosil... Date of discharge..... Diegnosi.... Days in hospltal ....

14. If dead, date of death..............

15. Condition on di coharge (a) actire.............. (b) improved.......

(c) unimproved.

(d) quiescont.......

(e) apparontly arreated

$d, \ldots \ldots \ldots \ldots \ldots \ldots$

Sputum on disoharge

(a) negatire.

(b) positive.........

16. Vooational training at Sanatorium Yo..... No ......

17. Fanily (11st all 11ving in sane household) Have or Present Neme Date of Dirth rel, to patient had T.B. Health

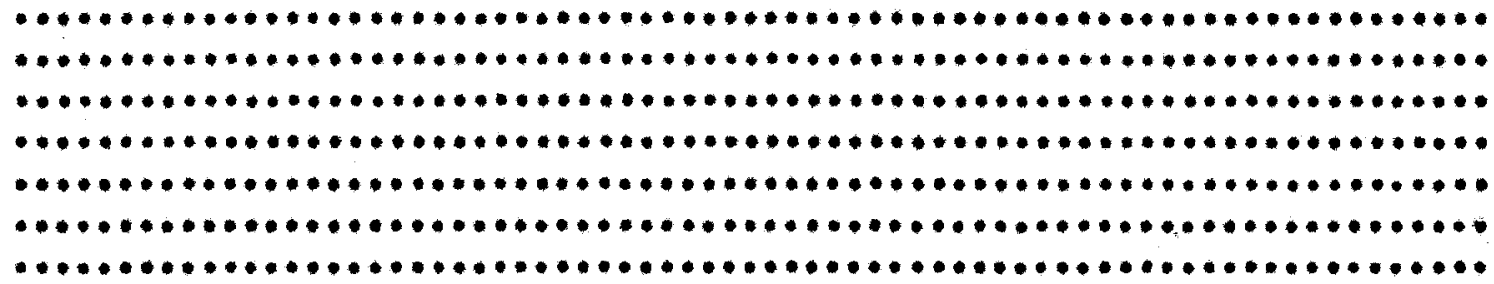

18. Financial status on achission (a) was patient self-supporting?....... if not, from whom was relief rocolved?...........................

19. Finnnolal status on disoharg*...... at time of home visit.......... 
20. Type of problene found:

1. Inadequate or lack of inoome

2. Unemployments

3. Illness or disability

4. Broken foully

5. Behavior Problea
(a) adult

(b) oh11d

6. Domertio diffioultios

7. Housing

(a) Inadequate

(b)

8. Inadequate uperviloton children

9. Problene of adolencenoe

10. Confliot with relative

11. Confl iot with community

12. Mental 11Inese

13. Mental defieleney

14. None

21. Income

1. Souree:
(a) private industry
(b) publlo essiotance (atate type)
(c) pension fron industry
(d) court ordar:
(o) assiotanoe from relatives
(f) boerder: and lodger:
(g) Army \& lavy pay
(h) deseribe any other
(1) no Inoame

(a) on diechargo

2. I. fontly

(a) wholly solf-supporting?

(b) partially alf-aupporting?

(o) wolly dependent on publ1a or private agonoy?

22. Home Condition:

(a) Ho. of rooms.... (c) sleep alone?...
(4) on diecharge

$\bullet \bullet+\bullet \cdot+\cdot \bullet$

$\cdots+\cdots \cdots \cdots \cdots$

$\bullet \bullet \bullet \bullet \bullet \bullet \bullet \bullet \bullet$

$\bullet \bullet \bullet \bullet \bullet \bullet \bullet \bullet$

$\cdots \cdots+\cdots+\cdots+*$

$\bullet \bullet \bullet \bullet \bullet \cdots+\cdots$

$\bullet \bullet \bullet \bullet \bullet \bullet \bullet \bullet$

$\bullet \bullet \bullet \bullet \bullet \bullet \bullet \bullet \bullet$

$\bullet \cdots \cdots \cdots \cdots+\cdots$

$\bullet \bullet \bullet \bullet \bullet \bullet \bullet+\cdots$

$\bullet \bullet \bullet * \bullet \bullet \bullet \bullet \bullet$

$\bullet \bullet \bullet \bullet \bullet \bullet \bullet \bullet \bullet$

$\cdots \cdots \bullet \bullet \bullet \bullet \bullet \bullet$

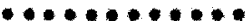

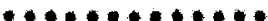

$\cdots \cdots \cdots \cdots$

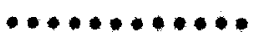

$\bullet \bullet \cdots+\cdots+\cdots$

$\cdots \cdots \cdots \cdots \cdots \bullet$

$\bullet \bullet \bullet \bullet * \bullet \bullet \bullet$

$\cdots+\cdots \cdots \cdots \cdots$

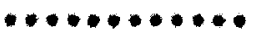

$\bullet \bullet+\cdots \cdots \bullet \bullet \bullet$

$\bullet \bullet \bullet+\cdots \bullet+\bullet$

$\bullet \bullet \bullet \bullet \bullet \bullet \bullet$

$\ldots \bullet \bullet \bullet \cdots * \bullet$ $\bullet \bullet \bullet \bullet \bullet \bullet \bullet \bullet \bullet \bullet$ (b) at time home visit

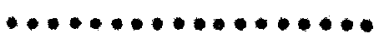

$\bullet \bullet \bullet \bullet \bullet \bullet \bullet \bullet \bullet \bullet \bullet \bullet \bullet \bullet \bullet \bullet$

$\bullet \bullet \bullet \bullet \bullet \bullet \bullet \bullet \bullet \bullet \bullet \bullet \bullet \bullet$

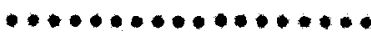

$\bullet+\cdots \bullet * \bullet+\cdots+\cdots \cdots$

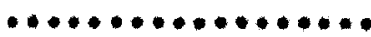

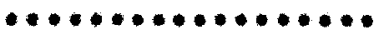

$\bullet \bullet \bullet \bullet \bullet \bullet \bullet \bullet \bullet \bullet \bullet \bullet \bullet \bullet \bullet$

$\bullet \bullet \bullet \bullet+\cdots \bullet \bullet \bullet+\cdots \cdots$

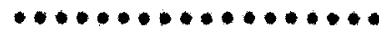

$\bullet \bullet \bullet \bullet \bullet \bullet \bullet \bullet \bullet \bullet \bullet \bullet \bullet$

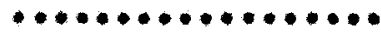

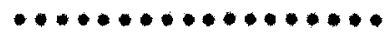

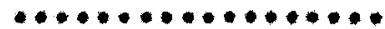

$\cdots \cdots \cdots+\cdots \cdots \cdots \cdots \cdots$

(b) at time home visit

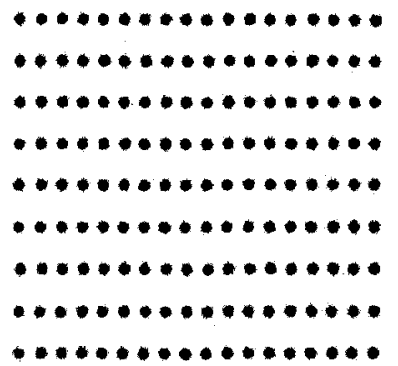

(b) Patient rooun alone?..............

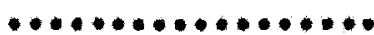

25. SSX Clearinge:

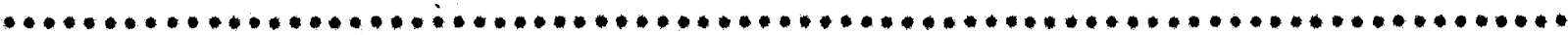

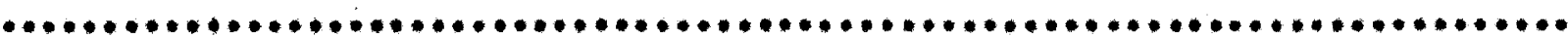

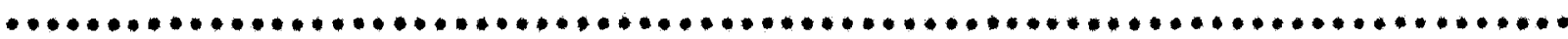

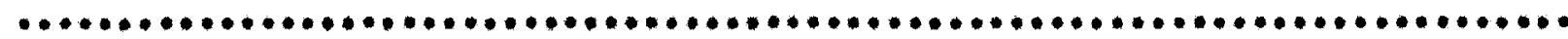

(a) Hame of agenoy attive if any ........................................

24. What modien ouperviation since discharge?
(a) Dates:
From....... to
(b) by

25. Date (a) of last exanination.....

(b) last $x-r a y$.

(o) Remilt.

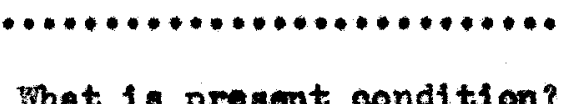

26. That is present condition?.

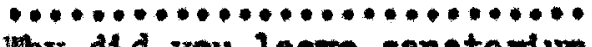

27. Why did you leave sanntoriun. 
APPBNDIX c

\begin{tabular}{|c|c|c|c|c|c|c|c|c|c|}
\hline Fiame of patient & addreas & $g$ & $\begin{array}{l}\text { others in } \\
\text { household }\end{array}$ & age & $\begin{array}{l}\text { rel. to } \\
\text { pationt }\end{array}$ & $\begin{array}{l}\text { have } \\
\text { or } \\
\text { had T.B. }\end{array}$ & $\begin{array}{l}\text { date last } \\
\text { exma }\end{array}$ & $\begin{array}{l}\text { Date } \\
\text { last } \\
x-\text { ray }\end{array}$ & $\begin{array}{c}\text { resul } \\
\& \\
\text { recom. }\end{array}$ \\
\hline & & & & & & & & & \\
\hline & & & & & & & & & \\
\hline & & & & & & & & & \\
\hline & & & & & & & & & \\
\hline & & & & & & & & & \\
\hline & & & & & & & & & \\
\hline & & & & & & & & & \\
\hline & & & & & & & & & \\
\hline & & & & & & & & & \\
\hline
\end{tabular}


BIBLIOCRAFIX 


\section{BIBLIOCRAPHY}

Assooletod Char1t1es, Cinolnnat1, "Roport A. C. Consultation Service Rendered T.B. Sanatorium", November, 1935.

Bartlett, Harriett $M .$, "Ewotional Elemente In IIlness: Responsiblilties of the Medion Soclal Worker", The Fam11Y, A pr11, 1940, Pp. 39-47.

"Soc1al Case Work: The Central Funotion of a Med1cal Soo1al Sorv10e Department", The Fam11y, 1938, Pp. 247-251.

Copp, Traoy, "Fodersl and State Programe of Vocational Rohabilitetion", Vocational Rehabilitation of 100 of gducation, Washington, D. C. (n.d.)

"Counseling The Tuberoulosis Patient", Tuberculosis Abotracts, XII, No. 1, January, 1939.

Elton, Fredriok a., "A Suggested Program of Vocational Activity for the sanetorium", Reprinted from Occupational Therapy and Rehabilitation, Vol. 20, No. 3, January, 1941, Pp. 159-165.

Grant, Irene, "Soc1el Work with Tuberculous Patlents", The Fam12Y, October, 1932, Pp. 190-198.

Hloks, Clarenoo M., "The Pajohotherapy of Rehabilitation of Patlonts in Tuberculosis Hospitals", The American Reviow of Tuberoulos1s, January, 1938.

Lawronoe, Wm. F., "What Happens to Patlente Discharged from Tuberoulos 1: Sanatoria", National Tuberoulosis Assoolation Soc1al Research, Ser10s Yo. 3 - N.Y., 1933.

Levine, Diana Bellen, "Supplementary Roport A. C. Consultation Service Rendered T.B. Sanatorium", Cincinnat1, March 16, 1936.

"Report of T.B. Advisory Cormittee, June 17, 1936.

"Family Consultation Service to Tuboroulosia Sanatorlum", Clnolnnat1, July 28, 1936. 
Loulav111e Jefferson County Health Department,

"To Help You Regain Your Health". (n.d.)

Newapaper C11ppinge Irom Lou1av111e Cour1er-Journal

and Tines, 1940 - T94E.

Report of the Mayor' a Conference Committee on

Tuberculosis, "Fradiontion of Tuberculosia

In Syracuse", July, 1948.

Smalley, Ruth, "Paychiatric Implioations for Modical Soolal Work", The Pamily, December, 1934, Pp. 257-265.

Terry, C. Foster, "Rohebilitation and After Care of the Tuberoulous", Reprinted from the Amorlean Revien of Tuberculosie, Vol. XIIII, No. 2 , Fobruary, 1941.

Unlted states orfice of Education, Vocational Rehabliltation D1vision, "Pulmonary Tuberculosia", M1se. 2388 (Revieed), Washington, D. C.. Apr11, 1941.

Whitney, J. S. and Dempery, Mary V., "A study of Patients D1soharged A11ve rrom Tuberoulosis Sanatoria in 1933, Hetional Tuberaulosie Association social Research Soried yo. E, Trational Iubereulosis Aasociation, 1972.

Yooum, Susan Folkes, "Cese Work with the Physically III", The Fan117, November, 1839, Pp. 216-221. 